Marquette University

e-Publications@Marquette

8-1-2015

\title{
Does Education Increase Pro-Environmental Behavior? Evidence From Europe
}

Andrew G. Meyer

Marquette University, andrew.g.meyer@marquette.edu

NOTICE: this is the author's version of a work that was accepted for publication in Ecological Economics. Changes resulting from the publishing process, such as peer review, editing, corrections, structural formatting, and other quality control mechanisms may not be reflected in this document. Changes may have been made to this work since it was submitted for publication. A definitive version was subsequently published in Ecological Economics, Vol. 116, (2015): 108-121. DOI. (C) 2015 Elsevier. Used with permission. 


\title{
Does Education Increase Pro-Environmental Behavior? Evidence from Europe
}

\author{
Andrew Meyer ${ }^{+}$
}

\begin{abstract}
It is often observed that individuals with higher education levels tend to be more environmentally friendly. Yet, the causal evidence is lacking because there may well be omitted variables that cause individuals to attain more education and also cause individuals to be environmentally conscious. We implement a regression discontinuity design to estimate the increase in educational attainment due to changes in compulsory education laws in $20^{\text {th }}$ century Europe. This allows us to overcome the identification problem of endogenous educational attainment. Using two waves of Eurobarometer surveys, we find a positive local average treatment effect for 7 of the 8 pro-environmental behaviors. An analysis of related questions on the survey supports the notion that education causes individuals to be more concerned with social welfare and to accordingly behave in a more environmentally friendly manner.
\end{abstract}

Keywords: instrumental variables; pro-environmental behavior; education; Europe

JEL Codes: I2; H4; H23; Q5 


\section{Introduction}

Many studies find an association between higher education levels and concern for the environment

(for example, Blomquist and Whitehead, 1998; Brecard et al., 2009; De Silva and Pownall, 2014;

Klineberg et al., 1998; Torgler and García-Valiñas, 2007). However, it is not clear that this is a causal effect. That is, individuals choose how much education to attain and also choose how to behave in relation to the environment. Any omitted characteristic that is correlated with educational attainment and the extent of pro-environmental behavior will bias the estimated relationship between these variables in a standard regression framework. It could be that individuals who attain more education are different in unobservable ways which lead them to also care more about environmental issues. For example, personal responsibility, work ethic, or social conscience could affect the extent of educational attainment and could also determine one's extent of pro-environmental behavior. If we could adequately measure these variables and control for them in our analysis, there would be no issue. However, it is unlikely that we can adequately control for all of these personal characteristics that determine educational attainment and proenvironmental behavior.

Furthermore, from a public policy perspective, it is the causal relationship that is of highest interest rather than a descriptive relationship. A causal estimate can tell us what we would expect to happen in an alternative world where individuals attain higher levels of education. Thus, a causal estimate can give us a better idea of what would happen to the extent of pro-environmental behavior if we could, for example, reduce secondary school dropout rates. Existing literature informs only on the descriptive relationship between education and environmental behavior and not on the causal relationship. This is precisely our contribution; we provide the first individual level results on the causal effect of education on pro-environmental behavior. 
How do we establish a causal relationship? We adopt an instrumental variables identification strategy that has been used elsewhere in studying the effects of education dating back to the seminal paper by Angrist and Krueger (1991); we instrument for education with changes in compulsory education laws. Changes in compulsory education laws serve as a natural experiment and provide the needed exogenous source of variation in educational attainment to uncover a causal relationship. Following Brunello et al. (2009) and Gathmann et al (2014), we pool together data from multiple European countries to estimate the average effect of many reforms that were implemented in Europe throughout the twentieth century. The benefit of this multicountry approach is that we can utilize a large scale survey data source containing information on pro-environmental behavior. Limiting the analysis to one particular reform would not yield enough observations on pro-environmental behavior to establish whether or not education has a causal effect. Additionally, in a multi-country approach, there is less chance that we will find results that are peculiar to only one specific reform.

We analyze data from two Special Eurobarometer surveys, conducted in 2007 and 2011 on a representative EU sample. These surveys ask a group of questions concerning the recent proenvironmental behaviors of respondents. Additionally, the surveys collect demographic information including age, country of residence, and the age at which the respondent finished their education. Thus, we can identify individuals who were likely born in a country near the time of an educational reform that changed the number of years of required education. Differences in the educational attainment of individuals born shortly before and after the enacting of the reform can then be attributed to the reform, helping us to overcome the endogeneity of education. Consistent with previous studies utilizing European compulsory education reforms, we find that a reform is expected to increase educational attainment by approximately 0.3 to 0.5 years. 
In our analysis of the causal effect, we find that an extra year of education is expected to increase the probability that an individual conducts seven out of the eight examined proenvironmental behaviors. The local average treatment effect is positive and significant for the following seven pro-environmental behaviors ${ }^{1}$ : using environmentally friendly travel $(0.024)$, reducing disposables (0.03), separating waste for recycling (0.066), reducing energy consumption (0.027), purchasing environmentally labeled products (0.061), purchasing local items (0.043), and reducing car usage (0.019). Thus, from a societal standpoint, there are benefits of education that have not been recognized in full. Furthermore, we provide an analysis of environmental opinion questions on the survey to explore potential explanations for why education increases proenvironmental behavior. This analysis suggests that education may increase the perceived importance of environmental issues. This is consistent with the explanation that education causes individuals to be more concerned with overall social welfare, including the external benefits of their actions.

\section{Previous Literature}

Many studies have addressed the returns from education, where the effect on earnings from increased education is the most researched area (Aakvik et al., 2010; Angrist and Krueger, 1991; Acemoglu and Angrist, 2001; Meghir and Palme, 2005; Oreopoulos, 2006a, 2006b; among others). Additionally, there is a growing literature on the non-pecuniary benefits of education. ${ }^{2}$ Health is often identified as one leading non-pecuniary benefit of education, although the evidence in this area is mixed. For example, some research finds that education improves health outcomes including mortality (Cipollone and Rosolia, 2011; Lleras-Muney, 2004; van Kippersluies et al.,

\footnotetext{
${ }^{1}$ The size of the LATE, representing the average increase in the probability of a complier performing the behavior within the last month, is given in parentheses.

${ }^{2}$ For a recent review, see Oreopoulos and Salvanes (2011).
} 
2011) while others find no such reduction in mortality due to education (Albouy and Lequien, 2009; Clark and Royer, 2013). Other research finds that increases in compulsory education reduce teenage births (Black et al., 2008), reduce crime (Lochner and Moretti, 2004) and cause civic participation, including voting, to increase (Milligan et al., 2004). Using different data and a different empirical approach, Dee (2004) also finds that increased educational attainment increases political involvement.

There is an extensive literature on socioeconomic predictors of pro-environmental behavior. Torgler and García-Valiñas (2007) provide a thorough literature review on studies that have examined the factors related to environmental attitudes including age, gender, marital status, education, and economic status. Since we contribute to the literature on the environmental behavior effects of education, we concentrate here on examples of the studies that investigate the role of education in environmental attitudes and behavior. ${ }^{3}$ Many papers find that education is positively correlated with pro-environmental behavior in a range of contexts. For example, multiple studies find that individuals with higher education are more likely to recycle (Callan and Thomas, 2006; Duggal et al., 1991; Ferrara and Missios, 2005; Reschovsky and Stone, 1994; Smith, 1995). Other research finds that education is correlated with food choices that affect the environment. For example, Blend and Van Ravenswaay (1999) find that higher levels of education increase the probability that a consumer would purchase eco-labeled apples. Several others find that education is associated with a higher probability of purchasing organics (Bellows et al., 2008; Monier et al., 2009; Zepeda and Li, 2007). Some studies have found that higher education levels are correlated with water saving behaviors (Berk et al., 1993; Gilg and Barr). Similarly, there is prior evidence

\footnotetext{
${ }^{3}$ Many papers related to environmental issues, especially stated-preference studies, include education as an explanatory variable. It is not feasible to review every one of these studies here but we attempt to include the studies that have demographic predictors of environmental attitudes or behaviors as their primary focus. We summarize these studies in Appendix Table A1.
} 
that higher education levels are associated with energy saving behavior (Mundaca et al., 2010; Poortinga et al., 2004). Furthermore, there is evidence that education is associated with more proenvironmental attitudes. For example, Rowlands et al. (2003) find evidence that more educated individuals are willing to contribute more for green electricity. De Silva and Pownall (2014) find that college educated individuals are more likely to sacrifice financial well-being to improve environmental quality and Xiao et al. (2013) find that more highly educated Chinese citizens report higher levels of environmental concern. Torgler and García-Valiñas (2007) show that not only years of formal education matter for explaining pro-environmental attitudes, but also informal education which they proxy with measures of political interest.

However, the literature does not uniformly find a positive association between proenvironmental attitudes or behavior and education. Some studies find no evidence of an association or even that education is negatively associated with pro-environmental attitudes or behavior. Ek and Soderholm (2008) find little evidence that education levels explain the choice of green electricity. Likewise, Kriström and Kiran do not find evidence that education explains energy consumption. Ayalon et al. (2014) do not find an effect of education on recycling behavior. Wessells et al. (1999) find no evidence that more education is associated with consumers' willingness to purchase ecolabeled seafood and Millock and Nauges (2014) find no effect of education on organic food consumption. Teisl et al. (2008) find that more educated people are more likely to trust eco-labels and find eco-information more important but also are more likely to rate eco-labeled vehicles lower. This may help explain why Johnston et al. (2001) find that Norwegian survey respondents having at a 4 year higher education degree are less likely to purchase ecolabeled seafood and why Thompson (1998) and Thompson and Kidwell (1998) conclude that individuals with advanced degrees may purchase less organics. Finally, Grafton 
(2014) find a negative association between education level and water conservation. These studies all provide valuable information on how education can predict environmental behavior. However, the potential for omitted variables that are correlated with both educational attainment and environmental attitudes can make it difficult to infer causality from these findings.

Some descriptive analysis of the data from the Special Eurobarometer surveys is provided in the respective reports published as Special Eurobarometer 295 (2008) and Special Eurobarometer 365 (2011). For example, Special Eurobarometer 295 (2008) states that a person who tends to refrain from pro-environmental behaviors tends to also have less full-time education. Furthermore, Special Eurobarometer 365 finds that " $73 \%$ of respondents who studied until the age of 20 or older say that they separate their waste for recycling, compared with $63 \%$ of those who finished school before the age of 16" (2011). The same report also mentions descriptive differences in energy reduction behavior and all the other items, "indicating that respondents with a level of higher education are consistently more likely to carry out all the activities listed than those who finished their education earlier" (Special Eurobarometer 365, 2011). Thus, there is prior descriptive evidence that higher education levels are correlated with higher probabilities of proenvironmental behavior. However, the short-coming of this descriptive analysis is that it does not establish that it is education that is causing the increase in pro-environmental behavior. It is this investigation of the causal effect that sets our analysis apart from the previous findings.

\section{Data}

Data for this analysis come from two waves of Eurobarometer surveys. Eurobarometer surveys are public opinion surveys conducted by the European Commission. The European Commission conducts Standard Eurobarometer surveys on a biannual basis and Special Eurobarometer surveys periodically. We use data from two Special Eurobarometer surveys on environmental issues; these 
are Eurobarometer 68.2, which collected responses from November 2007-January 2008, and Eurobarometer 75.2, which collected responses from April-May 2011. Both surveys were designed to be representative of the EU population and all surveys were conducted using face-to-face interviews following uniform protocols. Both Eurobarometer surveys collected approximately 1000 interviews per country and followed the same protocols with the same survey design. Furthermore, both surveys ask a group of identical questions about environmental issues and proenvironmental behaviors and collect the same demographics. Thus, we pool the surveys together into one sample of 53,555 individual level observations (26,730 from Eurobarometer 68.2 and 26,825 from Eurobarometer 75.2).

Eurobarometer 68.2 and 75.2 ask a question about various pro-environmental behaviors. The question is phrased as, "Have you done any of the following during the past month for environmental reasons?" The exact wording of the 8 possible pro-environmental behaviors is as follows:

- Chosen an environmentally friendly way of traveling (by foot, bicycle, public transport)

- Reduced the consumption of disposable items (for example plastic bags, certain kind of packaging, etc.)

- Separated most of your waste for recycling

- Cut down your water consumption (for example not leaving water running when washing the dishes or taking a shower, etc.)

- Cut down your energy consumption (for example turning down air conditioning or heating, not leaving appliances on stand-by, buying energy saving light bulbs, buying energy efficient appliances, etc.)

- Bought environmentally friendly products marked with an environmental label 
- Chosen locally produced products or groceries

- Used my car less

We first group these behaviors together into one variable, Pro-environmental Behaviors, which can range from 0 to 8 simply representing the reported count of the possible eight behaviors. This should be a good proxy of the intensity of an individual's pro-environmental behavior because it captures a range of possible behaviors. All else equal, individuals who do more of these things are likely behaving in a more environmentally friendly manner. However, we acknowledge that this dependent variable has some limitations. By grouping these behaviors into one variable, we are implicitly assuming that they each carry the same weight and are substitutable; these may not be good assumptions. For example, the environmental impact of choosing locally produced products or groceries may be very different from the environmental impact of reducing energy consumption. Also, some of the behaviors deliver cost savings and some are costly. Thus, it is not clear how to interpret the scale of the marginal effect when using this grouped dependent variable. Nevertheless, collapsing the behaviors into one variable is beneficial in that we can demonstrate the stability of the estimation results across several empirical approaches. Then, we examine each behavior on its own as a dichotomous dependent variable to provide results that are more economically meaningful.

Next, we code our educational reform variable. Changes in compulsory education laws provide the exogenous variation to identify the causal effect of education on pro-environmental behavior. Following Brunello et al. (2009) and Gathmann et al. (2014) we pool together multiple reforms over multiple countries. Specifically, we utilize compulsory school reforms that occurred at different times in the $20^{\text {th }}$ century across 14 European countries. Brunello et al. (2009) and 
Gathmann et al. (2014) detail these educational reforms in the respective papers. ${ }^{4}$ There is significant overlap between the two studies, with the main differences being that Brunello et al. (2009) do not include any data from the UK and do not include some of the very early reforms of the $20^{\text {th }}$ century. Both studies point to Fort (2006) as the main comprehensive data source of these reforms. Fort (2006) has meticulously documented these reforms to provide as many additional checks on their reliability as possible. Nevertheless, the historical development of the educational system within some European countries is complicated, with the exact date of implementation sometimes under dispute (Fort, 2006). Therefore, in the interest of comparability across studies, we take the year of implementation and the year of the first affected cohort from these previous studies. For each reform included in our sample, Table 1 presents the date of the reform, the change in the minimum schooling level, and the year of birth of the first cohort potentially affected by the reform.

It is worth noting a few details about these educational reforms. All of the reforms increased the minimum schooling level by a minimum of 1 up to a maximum of 4 years. The first cohorts affected by the reforms were born between 1932 and 1969, with 20 of the 30 reforms first affecting cohorts born in the 1940's and 1950's. Most of the reforms move the minimum leaving age up to the $9^{\text {th }}$ or $10^{\text {th }}$ grade, so these reforms are likely affecting individuals from the lower end of the schooling distribution. Despite the differences in the structural details of the reforms across time and countries, previous evidence has shown that, "surprisingly, the impact of these reforms on educational attainment is nearly +0.3 additional years of schooling, exhibiting little cross-country

\footnotetext{
${ }^{4}$ Brunello et al. (2009) describe their reforms in detail in an online appendix available at http://www.res.org.uk. Gathman et al. (2014) describe their reforms in detail in an online appendix available at http://www.journals.elsevier.com/social-science-and-medicine/. These reforms all focus on the number of years added to compulsory education. As pointed out by a referee, there are potentially other reforms relating to content, especially anything related to the environment, which could be important in explaining the adoption of proenvironmental behaviors. This is an interesting question and worthy of further study but we do not have any information on the content of reforms as they relate to the environment.
} 
variation" (Fort, 2006). Thus, researchers have adopted these reforms as a valid instrument that, on average, increased average educational attainment.

To identify which individuals in our sample are affected by a reform, we need to identify each individual's birth year. The Eurobarometer surveys do not provide birth years, but they do provide the age of the survey respondent. Since Eurobarometer 68.2 was conducted from November 2007-January 2008, we can determine the birth year with a high probability for these individuals. For example, for a survey conducted in December 2007, 11 out of 12 individuals would have already had their birthday in 2007. So, we calculate their birth year as (2007 - age). However, it is not as clear for Eurobarometer 75.2, which was conducted April-May 2011. For example, for a survey conducted on April 30, 2011, 4 out of 12 individuals would have already had their birthday in 2011, but 8 out of 12 individuals would not have yet had their 2011 birthday. ${ }^{5}$ For those with birthdays between January 1 and April 30, the correct calculation for the birth year would be (2011 - age). For those with birthday between May 1 and December 31, the correct calculation for the birth year would be $(2011$ - age - 1). However, we cannot know which the correct calculation for any one individual is. Thus, we go with the majority case and code the birth year for all individuals in the 2011 survey as (2011 - age - 1).

We then construct our pre-reform and post-reform samples in the same manner as Brunello et al. (2009). That is, define $k=\left(b-b_{j}\right)$ as the number of years between birth cohort $b$ and the pivot cohort $b_{j}$. The pivot cohort, $b_{j}$, is the first cohort that was potentially affected by the change in the compulsory education law in country $j$. As our baseline, we utilize the cut-off point of $k=12$, so the pre-reform sample includes all individuals born in country/region $j$ in the 12 years prior to $b_{j}$ and the post-reform sample includes all individuals born in country/region $j$ in the 12 years

\footnotetext{
${ }^{5}$ In fact, it is likely more than 8 out of 12 who would have not yet had a 2011 birthday because there tend to be more births in summer months than in winter months.
} 
subsequent to $b_{j}$ (excluding those born in $b_{j}$ ) ${ }^{6}$ Each selected reform was enacted at a different point in time so the instrument varies across countries and across different birth cohorts. Table 2 shows the composition of our sample across countries/regions for this bandwidth of 12 years before and after the reform. We note that Great Britain ${ }^{7}$ provides the second largest number of observations to the sample. Other studies have shown that the compulsory education reforms enacted in Great Britain were particularly successful in increasing average educational attainment (Clark and Royer, 2013; Oreopoulos, 2006a).

Note that an individual will only be included in our sample for analysis if they have a birth year that falls within this bandwidth. Therefore, as the bandwidth gets larger the sample size increases and we have potential for greater precision. However, doing so comes at the risk of introducing other confounding factors that could affect educational attainment and the extent of pro-environmental behaviors. Conversely, as we narrow the bandwidth, the sample size decreases and we lose some potentially valuable information. However, a narrower window provides greater confidence that any differences in educational attainment are due to changes in the compulsory education laws rather than other factors. Therefore, we alter the size of this window to be larger or narrower to investigate the robustness of the results.

The Eurobarometer surveys ask a question about educational attainment; the question is phrased as, "How old were you when you stopped full-time education?" Therefore, we do not directly observe the number of years of education. However, this question should be a good proxy for number of years of education. In our analysis, this will simply shift up the constant in the regression, but should not substantially change the parameter coefficients with one caveat. In the

\footnotetext{
${ }^{6} 12$ years is the widest bandwidth that we can choose without having individuals enter into the sample from two different reforms. We exclude individuals born in $b_{j}$ because we are unable to identify whether or not they were treated with the reform.

${ }^{7}$ Great Britain includes England, Scotland, and Wales.
} 
case of individuals having gaps in their education, using education age as a proxy for educational attainment would overstate the effect of reforms on educational attainment. For example, two individuals, $A$ and $B$, can both report an education age of 24 with Individual $A$ attaining 16 years of education and Individual $B$ attaining 19 years of education. The higher the sample percentage of people like Individual A, the more we will overstate the effect of reforms on educational attainment. Hence, the higher the sample percentage without gaps in education, the less we will overstate the effect of reforms on educational attainment. ${ }^{8} \mathrm{We}$ assume that educational attainment increases only until age 25 and exclude individuals who report an age greater than 35 at the time when they stopped full-time education. ${ }^{9}$ Table 3 presents summary statistics for each of our variables.

\section{Empirical Strategy}

We want to identify the effect of additional education on pro-environmental behavior. There are likely unobserved characteristics of individuals that can explain both educational attainment and the level of pro-environmental behavior. Thus, we need an exogenous source of variation that can explain educational attainment; this instrument is the changes in compulsory schooling laws. For the changes in compulsory schooling laws to be a valid instrument, the reforms must be able to explain average differences in educational attainment. To begin, we present some graphical evidence of the effects of the reforms on education age. In Figure 1, we plot the average education age for each of the cohorts for several years before and after the year of the reform. We then run two separate regressions of education age on $k$ with one regression for the pre-reform sample and

\footnotetext{
${ }^{8}$ Likewise, we cannot identify which individuals retook academic years. This should not contaminate our results as long as the retakes are not correlated with the timing of the reforms.

${ }^{9}$ We choose 25 because this is the first age that one could potentially complete a Ph.D. without any gaps in their education. There are a small percentage of individuals that report an age much higher than 35 when they stopped full-time education. Including them in the sample does not change statistical significance of the results but does cause the relevant point estimates to slightly change.
} 
one for the post-reform sample. We overlay the fitted values from these regressions on Figure 1. The vertical distance between the two regression lines just before the reform $(k=-1)$ and just after the reform $(k=1)$ then gives a sense of the size of the effect of reform on education age; this distance is $18.663-18.252=0.411$ years. Thus, the effect is noticeable from a graphical standpoint.

It must be the case that changes in the compulsory schooling laws have no direct effect on pro-environmental behavior for the reforms to be a valid instrument. That is, the reforms must work through the individual's education level to affect pro-environmental behavior. We would not have a valid instrument if increases in compulsory schooling laws are associated with unobservable factors that also cause pro-environmental behavior to increase. However, recall the timing of the reforms. A reform is put into place when a treated individual is either in primary school, or preschool, or not yet even born. Because the reforms took place long before the Eurobarometer surveys on pro-environmental behavior, the average age of an individual in our sample is 53, and the youngest individual is 26 . Thus, for most our sample, unobservable factors at the time of the reform would need to directly affect one's pro-environmental behavior decades later to make the instrument invalid. Given that this is quite unlikely, an instrumental variables estimation approach is appropriate. Thus, our analysis proceeds using two stage least squares; we first estimate the effect of the compulsory law changes on educational attainment and then estimate the proenvironmental behavior effects of these changes.

Following the approach originally suggested by Oreopoulos (2006a), we use a regression discontinuity design to estimate the effects of the compulsory schooling law changes on educational attainment. This RD design has subsequently been used by others in the literature as well to identify the local average treatment effect (LATE) (Brunello et al., 2009; Clark and Royer, 2013; Gathmann et al., 2014). In this first stage, we specify educational attainment as 
education $_{i c}=\alpha_{0}+\alpha_{1} R_{i c}+f\left(k_{i c}\right)+\boldsymbol{X}_{i c}^{\prime} \alpha_{2}+$ Country $_{j}+$ Survey $_{2011}+\epsilon_{i c}$,

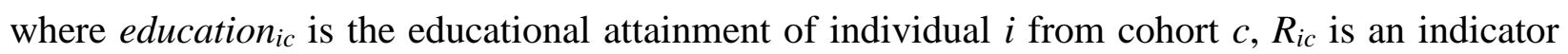
variable of whether the individual is a member of a post-reform (treated) cohort, $k_{i c}$ is an individuals' birth cohort measured in years relative to the pivot cohort, $\boldsymbol{X}_{i c}$ is a vector of exogenous explanatory variables including gender and age controls, Country $y_{j}$ are fixed effects for country $j$, Survey $_{2011}$ is an indicator for the 2011 Eurobarometer to control for differences across the two years of the survey, and $\epsilon_{i c}$ is the error term. Note that in this regression discontinuity design, we should be including only exogenous (predetermined to educational attainment) covariates. Predetermined covariates, such as gender controls and age, can help reduce the sampling variability in the RD estimates but should not affect our estimates of $\alpha_{1}$ because these covariates should be uncorrelated with the side of the cutoff in which one is born (Lee and Lemieux, 2010; Clark and Royer, 2013). However, covariates such as income, marital status, or number of children are determined jointly with educational choices or after one decides how much education to attain. As such, they are potentially endogenous and can bias our estimates of $\alpha_{1}$, so they should not be included in the regression design. ${ }^{10}$

There are two general approaches to identify the discontinuity parameter, $\alpha_{1}$ (Lee and Lemieux, 2010; Imbens and Lemieux, 2008). The polynomial approach models the cohort trends, $f\left(k_{i c}\right)$, with a parametric function such as a quadratic or quartic polynomial and uses either all the available data or all observations that fall within wide bandwidths of the reforms. The potential weakness of this approach is that any trends that are not adequately controlled with the parametric function could potentially bias the results. The local linear method is a nonparametric approach

\footnotetext{
${ }^{10}$ See pages 64-68, "Bad Control," in Angrist and Pischke (2009). As a robustness check, we estimate the model including additional covariates that are likely endogenous including household size, marital status, employment status, and location of residence. These results are shown in Tables A5 and A6 in the appendix and are very similar to the main results presented in the paper without these covariates.
} 
that uses only data that fall within narrower bandwidths of the reform and controls for cohort trends with a linear function of $k$. Interacting $k$ with the reform dummy, $R$, allows the cohort trends to have different slopes pre and post reform. The potential weakness of this approach is that one must choose the bandwidth to be narrow enough so that a linear approximation of the regression function does not result in large biases in the estimates. Thus, we utilize both approaches. We first specify the widest possible bandwidth that assures that no individual will be assigned to the pre or post reform sample for more than one reform; this corresponds to a bandwidth of 12 cohorts on each side of the birth cohort. Then, we narrow the bandwidth several times to see how the estimates from the polynomial control models and the local linear model compare. For the local linear model, we interact $k$ with the reform indicator to allow the regression function to have different slopes on either side of the pivot cohort.

Next, we specify the following model for pro-environmental behavior, $P E B_{i}$, $P E B_{i c}=\beta_{0}+\beta_{1}$ education $_{i c}+g\left(k_{i c}\right)+\boldsymbol{X}_{i c}^{\prime} \beta_{2}+$ Country $_{j}+$ Survey $_{2011}+\omega_{i c}$ where education $_{i c}$ is the endogenous educational attainment of individual $i$ from cohort $c, \boldsymbol{X}_{i c}$ is a vector of exogenous explanatory variables including gender and age controls, Country $y_{j}$ are country level fixed effects, Survey $y_{2011}$ is a dummy for the 2011 wave of the survey, and $\omega_{i c}$ is the error term. We estimate equation (2) with two stage least squares where the first stage regression for education includes the reform instrument as in Equation $1 .{ }^{11} \mathrm{We}$ include controls for cohort trends, $g\left(k_{i c}\right)$, as in the first stage regression. ${ }^{12}$

\section{Results}

\subsection{Grouped Behavior Results}

\footnotetext{
${ }^{11}$ We utilize Stata 11 (StataCorp, 2009) for all regressions.

${ }^{12}$ Again, any variable that can be thought of as an outcome of education should not be included in this equation because its inclusion can introduce selection bias (Angrist and Pischke, 2009).
} 
We begin by presenting results for the grouped pro-environmental behavior variable that ranges from 0 to 8 to establish the stability of the results across estimation strategies. We initially select a pre-and-post-reform window of 12 years $(|k| \leq 12)$ in Table 4 . The first column shows OLS results when we treat education as exogenous. The second and third columns present results for the IV regressions using quartic and quadratic controls, respectively. Finally, the fourth column shows IV estimates when utilizing the local linear method. In Columns 2-4, when treating education as endogenous, we find that an extra year of education leads to an increase of 0.265 to 0.269 pro-environmental behaviors. The IV estimates are several times larger than the corresponding OLS estimate. We may expect that the OLS estimate of the average treatment effect (ATE) would be biased upwards because individuals with more relative concern about the environment also tend to obtain more schooling. In this case, we should expect to find that IV estimates, which correct for the bias, should be lower than the corresponding OLS estimate. However, we note that the 2SLS estimate is the effect of an extra year of education on the compliers; these are the individuals for whom the educational reforms increase their educational attainment. In other words, this is the local average treatment effect (LATE) (Angrist and Pischke, 2009). As discussed in Card (2001) and Oreopoulos (2006a), IV estimates of the LATE could exceed the corresponding OLS estimates because the complier group is usually small and perhaps quite different from the general population. As shown in Brunello et al. (2009), for example, these compliers are likely to be individuals from the lower end of the ability and wealth distributions.

Table 4 also presents the first stage results for the three 2SLS specifications. First stage Fstats for the inclusion of the instrument are above the Stock and Yogo (2002) rule of thumb of 10 only for the quartic control model. However, in general, the magnitude of the coefficient on reform is similar to other estimates in the literature for the quadratic control and local linear models. For 
example, using a very similar sample, Gathman et al. (2014) find pooled coefficients of 0.501 for men and 0.541 for women. Clark and Royer (2010) estimate coefficients for the 1947 reform in England and Wales at 0.420 for men and 0.527 for women. Also, Oreopoulos (2006a) estimates a coefficient of 0.436 for men and women combined for the 1947 reform in Great Britain. Brunello et al (2009) estimate a range for the estimated impact of reforms on educational attainment, with the average being around 0.3 additional years of schooling. The estimates from studies involving the Great Britain reforms are larger than other estimates found in the literature, so our inclusion of the Great Britain reforms likely contributes to an estimate that is higher than it would be otherwise.

Next, we recognize that a window of \pm 12 years is wide enough that there could concern about confounding trends biasing the results, even with the polynomial controls. Therefore, in Tables 5, we decrease the bandwidth to 10 years. We also include results in the appendix for the bandwidths of 6 and 8 years pre and post reform. In each case, the estimates on education age remain statistically significant across all specifications. Furthermore, the results are quite stable, with the 2SLS estimates on education age ranging between 0.135 and 0.269 . Restricting attention to the bandwidths of 10 and 12 years pre and post reform, all 2SLS estimates on education age fall within 0.233 to 0.269 . This causal effect of education on pro-environmental behavior is economically significant. Relative to the mean of 3.24 environmental behaviors, this represents a 7.2 to 8.3 percent increase in the number of pro-environmental behaviors from one year of additional education.

The coefficient on reform remains highly statistically significant across all first stage regressions in Tables 5-7. However, the F-tests for the inclusion of the instrument are below 10 in all specifications of the quadratic and local linear control models. Thus, we may be concerned about marginally weak instruments from those models. It appears that the quartic control model 
does a better job of capturing cohort trends in education than do the other models. Looking at the average educational attainment values in Figure 1, it does seem that perhaps a higher order polynomial would do a better job of fitting the data, which is reinforced by the regression results.

Finally, in Appendix Table A4, we present results for the narrow windows where we only include 3, 4, or 5 pre and post reform cohorts. Here, we remove all time controls; we are estimating the model assuming that educational attainment and environmental preferences are not trending in any direction throughout the sample periods. While this is probably not an accurate assumption, it can be informative to compare these results with the results with the time controls. Educational attainment trends positively over time so we can view the coefficients from the first stage regressions in Table A4 as upper bounds on the effect of educational reforms on educational attainment. This suggests that the average impact of reform on educational attainment is less than 0.643 which is consistent with the earlier results.

As for demographics, we see in Appendix Table A5 that females display more proenvironmental behaviors than do males. This finding is consistent with most previous studies that examine the link between gender and pro-environmental behavior. Individuals in small/middle sized town and in large towns/cities display less pro-environmental behavior than people in rural areas. Furthermore, the level of pro-environmental behavior seems to decline with the size of the city of residence. Moreover, retired/disabled individuals report higher levels of pro-environmental behavior than employed individuals. This could relate to the opportunity cost of time; some proenvironmental behaviors are time/effort intensive and retired/disabled individuals perhaps face fewer demands on their time.

The structure of the household appears to have a relationship with the extent of proenvironmental behavior. Relative to married individuals, single individuals exhibit less pro- 
environmental behavior. There is also some evidence that individuals with larger households display more pro-environmental behaviors. It is not clear why the structure of the family correlates in these ways with pro-environmental behaviors, but this could be an interesting area for future research.

\subsection{Dichotomous Dependent Variable Results}

Next, we present results for each of the individual pro-environmental variables to provide more meaningful interpretations of the scale of the effect. We estimate a linear probability model on equations 1) and 2) for each of the 8 pro-environmental behaviors. ${ }^{13}$ For comparison, we also show results from the linear probability model and the probit model that treat education as exogenous for each of the individual behaviors. We present results for all of the individual pro-environmental behaviors in Table 6. These results for the dichotomous pro-environmental behaviors are consistent with what we see in the analysis of the grouped pro-environmental behaviors. We find positive associations between educational attainment and the probability of a pro-environmental behavior for each of the 8 behaviors in Columns 1 and 2 in the OLS and Probit results. Furthermore, when treating educational attainment as endogenous in Column 3 , we see a positive LATE for all but one of the dichotomous pro-environmental behaviors.

The scale of the LATE ranges from 0.0193 for the probability of reducing car usage to 0.0659 for the probability of separating waste for recycling. It is important to note here that the seven pro-environmental behaviors for which we find a positive LATE are quite different; additional education increases pro-environmental behavior in a wide variety of contexts. We elaborate on this further in the subsequent discussion section. Furthermore, we can conclude from

\footnotetext{
${ }^{13}$ We use a bandwidth of $(|k| \leq 12)$ and quartic controls for all results in this section. Results from narrower windows and from quadratic and local linear control models are similar and available upon request. We also alternatively estimate an IV probit model. Again, results are similar and available upon request.
} 
these results that not only do more highly educated individuals tend to behave in a more environmentally friendly manner, but that extra educational attainment actually causes the individual to increase their pro-environmental behaviors.

Interestingly, these results are quite similar in scale to those found in previous studies of the external benefits of education. For example, Dee (2004) estimates a LATE of increased education in the range of 0.037 to 0.069 for the probability of voting in the last election. And Milligan et al. (2004) find a similarly scaled LATE of increased education in the UK on measures of political involvement and citizenship. Additionally, we see strong evidence throughout that females have a higher probability of reporting pro-environmental behaviors. The only exception to this is the result for the probability of reducing car usage, which finds that males are more likely to report reducing their car usage than are females.

\section{Discussion}

We have thus far provided evidence of a causal effect of increased educational attainment on the extent of one's pro-environmental behavior. Here, we explore possible explanations for the reasons for the increase. When a utility maximizer decides how many environmentally friendly actions to take, they consider both the marginal cost and the marginal benefit of the pro-environmental actions. Take, for example, reducing energy consumption. Costs include the potential inconveniences or time costs of doing things in less energy intensive manners. Benefits include reducing air pollutants, which improves human and ecological health, and reducing personal monetary expenses associated with the purchase of energy. Thus it could simply be that, even with the same relative concern for environmental benefits, more educated individuals partake in more pro-environmental behaviors because they are more aware of the associated financial savings. In this explanation, more educated individuals are simply better economic optimizers and pro- 
environmental behavior is one place where this will manifest. We should then expect to find a larger LATE for the behaviors that provide a financial benefit to the self. Looking at Table 7, this does not seem to be the case. If anything, the point estimates of the LATE are larger for the behaviors that do not provide a financial benefit such as sorting waste for recycling, buying local products, and buying environmentally labelled products.

The Eurobarometer surveys also provide some questions that can help us further determine why more education leads to more pro-environmental behaviors. We analyze the responses to the following four questions. We code the dependent variables as dichotomous and estimate linear probability models. ${ }^{14}$

1) How important is protecting the environment to you personally? (very important or fairly important $=1$; not very important or not at all important $=0$; mean response $=0.961$ )

2) In general, do you consider that you are very well, fairly well, fairly badly or very badly informed about environmental issues? (very well informed or fairly well informed = 1; fairly badly informed or very badly informed $=0$; mean response $=0.338$ )

3) In your opinion, to what extent does the state of the environment influence your "quality of life"? (very much or quite a lot $=1$; not much or not at all $=0$; mean response $=0.803$ )

4) Environmental problems have a direct daily effect on your life. (totally agree or tend to agree = $1 ;$ tend to disagree or totally disagree $=0 ;$ mean response $=0.759)$

For each question, we estimate equations 2 and 3 with the substitution of the relevant dependent variable in place of pro-environmental behavior. Table 7 presents results for the model with quartic

\footnotetext{
${ }^{14}$ We alternatively code the dependent variables in levels, recognizing that the scale of the regression coefficients do not have direct interpretations since the scale in these answers may not be linear. The qualitative results remain the same and are available upon request.
} 
controls along with OLS results for comparison. ${ }^{15}$ We find evidence that education causes the personal importance of environmental issues to increase and that education causes individuals to perceive that environmental issues have a larger direct impact on their lives. Interestingly, there is no evidence that educational attainment has a causal effect on how well informed an individual perceives themselves to be on environmental issues. The scale of the results are similar to what we find in the analysis of the pro-environmental behaviors. This is consistent with the notion that education causes individuals to be more concerned with social welfare, and is a likely reason for the increase in the pro-environmental behaviors.

\section{Conclusion}

Previous research has established that there are desirable effects of increased educational attainment, with much of the research focusing on the wage effects. However, there is relatively little research establishing how educational attainment affects behavior outside of the marketplace. We contribute to the literature by documenting one such positive effect; increased educational attainment increases the extent of pro-environmental behavior. Studies have long documented a positive association between education levels and environmental preferences and behavior, but the causal evidence has largely been lacking because the observed correlations could be due to endogeneity of education. We overcome this problem by using changes in compulsory schooling laws as an instrumental variable, which has previously been established as an effective strategy.

We analyze data from two waves of special Eurobarometer surveys, which are designed to be representative of the European population. These surveys provide information on the extent of individuals' recent pro-environmental behaviors as well as their age, gender, and year of leaving fulltime education. We then pool together information from previous studies about many

\footnotetext{
${ }^{15}$ Results from quadratic control and local linear specifications are quite similar to the quartic control model and available upon request.
} 
educational reforms that were enacted in $20^{\text {th }}$ century Europe, which allows us to identify which individuals in the Eurobarometer survey were potentially affected by the reform. These changes in the reforms then become our instrumental variable, which we use in Two Stage Least Squares regressions of pro-environmental behavior on educational attainment. In the first stage, we utilize a regression discontinuity design to estimate the average increase in educational attainment due to the reform. In our second stage, we find that an extra year of education increases the probability of a pro-environmental behavior by 0.0193 to 0.0659 , depending on the specific behavior.

Our regression discontinuity design requires us to make a choice about the bandwidth of the pre and post reform periods. This choice requires a balance between making the bandwidth large enough to have sufficient observations and making the bandwidth small enough to avoid confounding factors. We initially choose a bandwidth of 12 years pre and post reform, but show that our results are robust to the choice of bandwidths that are considerably smaller than this. In such a design, one must also make a choice between polynomial controls and the local linear method to control for cohort trends. We investigate quadratic and quartic trends as well as the local linear method and find that the results are robust to all three models.

When interpreting these results, one should keep in mind that this LATE applies to the individuals who increased their education as a result of the education reforms (the compliers). The vast majority of the educational reforms utilized in this study increased the minimum schooling level to 9 or 10. Therefore, the compliers in this study are likely coming from the lower end of the schooling distribution. In other words, we are not able to say much of anything about the causal effect on pro-environmental behavior of increasing the amount of post-secondary education. This question is certainly important and worthy of further study but it would require a different instrumental variable. At the least, however, our results do suggest that reducing the number of 
dropouts from secondary education could have the effect of increasing pro-environmental behavior.

We find a substantial causal effect of educational attainment on pro-environmental behavior and provide some soft evidence that education may make individuals more aware of the external effects of their behavior and more concerned with social welfare. However, we do not have data that allow us to determine the specific underlying mechanism of this effect. Here, we posit some potential mechanisms. It could be that extra education specifically teaches individuals about the importance of the environment. Or, more broadly, it could be that extra education explicitly teaches individuals to be better citizens through the curriculum, and pro-environmental behavior is but one manifestation of this general effect. But, could it also be that extra educational attainment affects time preferences through indirectly teaching the virtues of patience? For example, if extra education lowers the personal discount rate or makes the individual less presentbiased, this could make an individual more likely to take on the immediate cost of proenvironmental behavior in exchange for the future benefit of the behavior. Or, is it that the extra education simply exposes individuals to other individuals who are especially environmentally conscious, and this pulls up the average pro-environmental behavior? This, for example, would be consistent with a social norms argument. We believe that it is important to have more research on these types of questions because they could provide insight into what types of interventions outside of the traditional educational system might also be more effective in increasing the extent of proenvironmental behavior in society at large.

\section{Acknowledgements}


We thank two anonymous referees for valuable comments that helped improve the quality of the paper.

\section{References}

Aakvik, A., Salvanes, K.G. \& Vaage, K. 2010, "Measuring Heterogeneity in the Returns to Education Using an Education Reform", European Economic Review, vol. 54, no. 4, pp. 483-500.

Acemoglu, D. \& Angrist, J. 2001, How Large Are Human-Capital Externalities? Evidence from Compulsory Schooling Laws, Volume 15. Cambridge and London: MIT Press.

Albouy, V. \& Lequien, L. 2009, "Does Compulsory Education Lower Mortality?", Journal of health economics, vol. 28, no. 1, pp. 155-168.

Angrist, J.D. \& Krueger, A.B. 1991, "Does Compulsory School Attendance Affect Schooling and Earnings?", Quarterly Journal of Economics, vol. 106, no. 4, pp. 979-1014.

Angrist, J.D. \& Pischke, J. 2009, Mostly Harmless Econometrics: An Empiricist's Companion, Princeton and Oxford: Princeton University Press.

Ayalon, O., Brody, S. \& Shechter, M. 2014, "Household waste generation, recycling and prevention" in Organisation for Economic Co-operation and Development, pp. 219-245.

Bellows, A.C., Onyango, B., Diamond, A. \& Hallman, W.K. 2008, "Understanding Consumer Interest in Organics: Production Values vs. Purchasing Behavior", Journal of Agricultural \& Food Industrial Organization, vol. 6, no. 1.

Berk, R., Schulman, D., McKeever, M. \& Freeman, H. 1993, "Measuring the impact of water conservation campaigns in California", Climatic Change, vol. 24, no. 3, pp. 233-248.

Black, S.E., Devereux, P.J. \& Salvanes, K.G. 2008, "Staying in the Classroom and Out of the Maternity Ward? The Effect of Compulsory Schooling Laws on Teenage Births", Economic Journal, vol. 118, no. 530, pp. 1025-1054.

Blomquist, G.C. \& Whitehead, J.C. 1998, "Resource quality information and validity of willingness to pay in contingent valuation", Resource and Energy Economics, vol. 20, no. 2, pp. 179-196.

Blend, J.R. \& van Ravenswaay, E.O. 1999, "Measuring Consumer Demand for Ecolabeled Apples", American Journal of Agricultural Economics, vol. 81, no. 5, pp. 1072-1077. 
Brecard, D., Hlaimi, B., Lucas, S., Perraudeau, Y. \& Salladarre, F. 2009, "Determinants of Demand for Green Products: An Application to Eco-label Demand for Fish in Europe", Ecological Economics, vol. 69, no. 1, pp. 115-125.

Brunello, G., Fort, M. \& Weber, G. 2009, "Changes in Compulsory Schooling, Education and the Distribution of Wages in Europe", Economic Journal, vol. 119, no. 536, pp. 516-539.

Callan, S.J. \& Thomas, J.M. 2006, "Analyzing Demand for Disposal And Recycling Services: A Systems Approach", Eastern Economic Journal, vol. 32, no. 2, pp. 221-240.

Card, D. 2001, "Estimating the Return to Schooling: Progress on Some Persistent Econometric Problems", Econometrica, vol. 69, no. 5, pp. 1127-1160.

Cipollone, P. \& Rosolia, A. 2011, Schooling and Youth Mortality: Learning from a Mass Military Exemption, C.E.P.R. Discussion Papers, CEPR Discussion Papers: 8431.

Clark, D. \& Royer, H. 2013, "The Effect of Education on Adult Mortality and Health: Evidence from Britain", American Economic Review, vol. 103, no. 6, pp. 2087-2120.

Dee, T.S. 2004, "Are There Civic Returns to Education?", Journal of Public Economics, vol. 88, no. 9-10, pp. 1697-1720.

De Silva, D.G. \& Pownall, R.A.J. 2014, "Going green: does it depend on education, gender or income?", Applied Economics, vol. 46, no. 5, pp. 573-586.

Duggal, V.G., Saltzman, C. \& Williams, M.L. 1991, "Recycling: An Economic Analysis", Eastern Economic Journal, vol. 17, no. 3, pp. 351-358.

Ek, K. \& Soderholm, P. 2008, "Norms and Economic Motivation in the Swedish Green Electricity Market", Ecological Economics, vol. 68, no. 1-2, pp. 169-182.

Ferrara, I. \& Missios, P. 2005, "Recycling and Waste Diversion Effectiveness: Evidence from Canada", Environmental and Resource Economics, vol. 30, no. 2, pp. 221-238.

Fort, M. 2006, Educational Reforms Across Europe: A Toolbox for Empirical Research, Working Paper. Available at: http://www2.dse.unibo.it/fort/files/papers/fort_reforms.pdf.

Gathmann, C., et al.. 2014. "Compulsory schooling reforms, education and mortality in twentieth century Europe", Social Science \& Medicine. In press.

Gilg, A. \& Barr, S. 2006, "Behavioural attitudes towards water saving? Evidence from a study of environmental actions", Ecological Economics, vol. 57, no. 3, pp. 400-414.

Grafton, R.Q. 2014, "Household behaviour and water use" in Organisation for Economic Cooperation and Development, pp. 149-181. 
Imbens, G.W. \& Lemieux, T. 2008, "Regression Discontinuity Designs: A Guide to Practice", Journal of Econometrics, vol. 142, no. 2, pp. 615-635.

Johnston, R.J. 2001, "Measuring Consumer Preferences for Ecolabeled Seafood: An International Comparison", Journal of Agricultural and Resource Economics, vol. 26, no. 1, pp. 20-39.

Klineberg, S.L., McKeever, M. \& Rothenbach, B. 1998, "Demographic predictors of environmental concern: It does make a difference how it's measured", Social Science Quarterly, vol. 79, no. 4, pp. 734-753.

Kriström, B. \& Kiran, C. 2014, Greening Household Behaviour and Energy, Organisation for Economic Co-operation and Development.

Lee, D.S. \& Lemieux, T. 2010, "Regression Discontinuity Designs in Economics", Journal of Economic Literature, vol. 48, no. 2, pp. 281-355.

Lleras-Muney, A. 2005, "The Relationship between Education and Adult Mortality in the United States", Review of Economic Studies, vol. 72, no. 1, pp. 189-221.

Lochner, L. \& Moretti, E. 2004, "The Effect of Education on Crime: Evidence from Prison Inmates, Arrests, and Self-Reports", American Economic Review, vol. 94, no. 1, pp. 155189.

Meghir, C. \& Palme, M. 2005, "Educational Reform, Ability, and Family Background", American Economic Review, vol. 95, no. 1, pp. 414-424.

Milligan, K., Moretti, E. \& Oreopoulos, P. 2004, "Does Education Improve Citizenship? Evidence from the United States and the United Kingdom", Journal of Public Economics, vol. 88, no. 9-10, pp. 1667-1695.

Millock, K. \& Nauges, C. 2014, "Household behaviour and food consumption" in Organisation for Economic Co-operation and Development, pp. 183-217.

Monier, S., Hassan, D., Nichele, V. \& Simioni, M. 2009, "Organic Food Consumption Patterns", Journal of Agricultural \& Food Industrial Organization, vol. 7, no. 2.

Mundaca, L., Neij, L., Worrell, E. \& McNeil, M. 2010, "Evaluating Energy Efficiency Policies with Energy-Economy Models", Annual Review of Environment and Resources, vol. 35, no. 1 , pp. 305-344.

Oreopoulos, P. 2006a, "Estimating Average and Local Average Treatment Effects of Education When Compulsory Schooling Laws Really Matter", American Economic Review, vol. 96, no. 1, pp. 152-175. 
Oreopoulos, P. 2006b, "The Compelling Effects of Compulsory Schooling: Evidence from Canada", Canadian Journal of Economics, vol. 39, no. 1, pp. 22-52.

Oreopoulos, P. \& Salvanes, K.G. 2011, "Priceless: The Nonpecuniary Benefits of Schooling", Journal of Economic Perspectives, vol. 25, no. 1, pp. 159-184.

Poortinga, W., Steg, L. \& Vlek, C. 2004, "Values, Environmental Concern, and Environmental Behavior: A Study into Household Energy Use", Environment and Behavior, vol. 36, no. 1, pp. 70-93.

Reschovsky, J.D. \& Stone, S.E. 1994, "Market incentives to encourage household waste recycling: Paying for what you throw away", Journal of Policy Analysis and Management, vol. 13 , no. 1 , pp. $120-139$.

Rowlands, I.H., Scott, D. \& Parker, P. 2003, "Consumers and green electricity: profiling potential purchasers", Business Strategy and the Environment, vol. 12, no. 1, pp. 36-48.

Smith, V.K. 1995, "Does Education Induce People to Improve the Environment?", Journal of Policy Analysis and Management, vol. 14, no. 4, pp. 599.

Special Eurobarometer 295. "Attitudes of European Citizens Towards the Environment. "2008, European Commission. Available at:

http://ec.europa.eu/public_opinion/archives/ebs/ebs_295_en.pdf.

Special Eurobarometer 365. "Attitudes of European Citizens Towards the Environment."2011, European Commission. Available at: http://ec.europa.eu/environment/pdf/ebs_365_en.pdf.

StataCorp. 2009. Stata Statistical Software: Release 11. College Station, TX: StataCorp LP.

Stock, J.H., Wright, J.H. \& Yogo, M. 2002, "A Survey of Weak Instruments and Weak Identification in Generalized Method of Moments", Journal of Business $\backslash \&$ Economic Statistics, vol. 20, no. 4, pp. 518-529.

Teisl, M.F., Rubin, J. \& Noblet, C.L. 2008, "Non-dirty Dancing? Interactions between Ecolabels and Consumers", Journal of Economic Psychology, vol. 29, no. 2, pp. 140-159.

Thompson, G.D. 1998, "Consumer Demand for Organic Foods: What We Know and What We Need to Know", American Journal of Agricultural Economics, vol. 80, no. 5, Proceedings Issue, pp. 1113-1118.

Thompson, G.D. \& Kidwell, J. 1998, "Explaining the Choice of Organic Produce: Cosmetic Defects, Prices, and Consumer Preferences", American Journal of Agricultural Economics, vol. 80, no. 2, pp. 277-287.

Torgler, B. \& García-Valiñas, M.A. 2007, "The determinants of individuals' attitudes towards preventing environmental damage", Ecological Economics, vol. 63, no. 2-3, pp. 536-552. 
van Kippersluis, H., O'Donnell, O. \& van Doorslaer, E. 2011, "Long-Run Returns to Education: Does Schooling Lead to an Extended Old Age?", Journal of Human Resources, vol. 46, no. 4, pp. 695-721.

Wessells, C.R., Johnston, R.J. \& Donath, H. 1999, "Assessing Consumer Preferences for Ecolabeled Seafood: The Influence of Species, Certifier, and Household Attributes", American Journal of Agricultural Economics, vol. 81, no. 5, pp. 1084-1089.

Xiao, C., Dunlap, R.E. \& Hong, D. 2013, "The Nature and Bases of Environmental Concern among Chinese Citizens", Social Science Quarterly, vol. 94, no. 3, pp. 672-690.

Zepeda, L. \& Li, J. 2007, "Characteristics of Organic Food Shoppers", Journal of Agricultural and Applied Economics, vol. 39, no. 01. 
Table 1. Reforms

\begin{tabular}{|c|c|c|c|c|}
\hline Country/Region & Reform Date & $\begin{array}{c}\text { First Cohort } \\
\text { Potentially } \\
\text { Affected }\end{array}$ & $\begin{array}{c}\text { Change in Min. } \\
\text { Schooling } \\
\text { Level }\end{array}$ & Source \\
\hline Austria & 1962 & 1953 & 8 to 9 & $\mathrm{~B}, \mathrm{G}$ \\
\hline Belgium & 1983 & 1969 & 8 to 12 & $\mathrm{~B}$ \\
\hline Denmark & 1971 & 1957 & 7 to 9 & $\mathrm{~B}, \mathrm{G}$ \\
\hline England and Wales & 1947 & 1933 & 8 to 9 & $\mathrm{C}, \mathrm{G}, \mathrm{O}$ \\
\hline England and Wales & 1973 & 1958 & 9 to 10 & $\mathrm{C}, \mathrm{G}$ \\
\hline Finland (Etela-Suomi) & 1976 & 1965 & 6 to 9 & B \\
\hline Finland (Ita-Suomi) & 1974 & 1963 & 6 to 9 & B \\
\hline Finland (Vali-Suomi) & 1973 & 1962 & 6 to 9 & $\mathrm{~B}$ \\
\hline Finland (Pohjois-Suomi) & 1972 & 1961 & 6 to 9 & $\mathrm{~B}$ \\
\hline France & 1959 & 1953 & 8 to 10 & B \\
\hline Germany (Schleswig-Holstein) & 1956 & 1941 & 8 to 9 & $\mathrm{~B}$ \\
\hline Germany (Hamburg) & 1949 & 1934 & 8 to 9 & $\mathrm{~B}$ \\
\hline Germany (Niedersachsen) & 1962 & 1947 & 8 to 9 & $\mathrm{~B}$ \\
\hline Germany (Bremen) & 1958 & 1943 & 8 to 9 & $\mathrm{~B}$ \\
\hline Germany (Nordrhein-Westphalia) & 1967 & 1953 & 8 to 9 & B \\
\hline Germany (Hessen) & 1967 & 1953 & 8 to 9 & $\mathrm{~B}$ \\
\hline Germany (Rheinland-Pfalz) & 1967 & 1953 & 8 to 9 & $\mathrm{~B}$ \\
\hline Germany (Baden-Wurtemberg) & 1967 & 1953 & 8 to 9 & B \\
\hline Germany (Bayern) & 1969 & 1955 & 8 to 9 & $\mathrm{~B}$ \\
\hline Germany (Saarland) & 1964 & 1949 & 8 to 9 & $\mathrm{~B}$ \\
\hline Greece & 1975 & 1963 & 6 to 9 & $\mathrm{~B}$ \\
\hline Ireland & 1972 & 1958 & 8 to 9 & $\mathrm{~B}, \mathrm{G}$ \\
\hline Italy & 1963 & 1949 & 5 to 9 & $\mathrm{~B}, \mathrm{G}$ \\
\hline Netherlands & 1950 & 1938 & 7 to 9 & $\mathrm{G}$ \\
\hline Netherlands & 1973 & 1959 & 9 to 10 & $\mathrm{~B}, \mathrm{G}$ \\
\hline Northern Ireland & 1957 & 1943 & 8 to 9 & $\mathrm{G}, \mathrm{O}$ \\
\hline Scotland & 1946 & 1932 & 8 to 9 & $\mathrm{G}$ \\
\hline Scotland & 1976 & 1958 & 9 to 10 & $\mathrm{G}$ \\
\hline Spain & 1970 & 1957 & 6 to 8 & $\mathrm{~B}, \mathrm{G}$ \\
\hline Sweden & 1962 & 1950 & 8 to 9 & $\mathrm{~B}, \mathrm{G}$ \\
\hline
\end{tabular}

Note: B = Brunello et al. (2009), C = Clark and Royer (2013), G = Gathman et al. (2014), $\mathrm{O}=$ Oreopoulos (2006) 
Table 2. Sample Composition

\begin{tabular}{lcc}
\hline Country & Obs & $\begin{array}{l}\text { Percent of } \\
\text { Sample }\end{array}$ \\
\hline Austria & 821 & 7.21 \\
Belgium & 825 & 7.24 \\
Denmark & 799 & 7.01 \\
Finland & 587 & 5.15 \\
France & 785 & 6.89 \\
Germany & 847 & 7.43 \\
Great Britain & 1274 & 11.18 \\
Greece & 820 & 7.20 \\
Ireland & 810 & 7.11 \\
Italy & 741 & 6.50 \\
Netherlands & 1,411 & 12.38 \\
Northern Ireland & 120 & 1.05 \\
Spain & 706 & 6.20 \\
Sweden & 847 & 7.21 \\
& & \\
Total & 11,393 & 100 \\
\hline
\end{tabular}

Table 3: Summary Statistics

\begin{tabular}{lccccc}
\hline Variable & Obs & Mean & Std. Dev. & Min & Max \\
\hline & & & & & \\
Education Age & 11,393 & 18.43 & 3.93 & 0 & 25 \\
Reform & 11,393 & 0.530 & 0.499 & 0 & 1 \\
Male & 11,393 & 0.473 & 0.499 & 0 & 1 \\
Age & 11,393 & 53.53 & 10.80 & 26 & 89 \\
Environmental Behaviors & 11,393 & 3.24 & 1.87 & 0 & 8 \\
Environmentally Friendly Travel & 11,393 & 0.340 & 0.474 & 0 & 1 \\
Reduce Disposables & 11,393 & 0.395 & 0.489 & 0 & 1 \\
Separate Waste for Recycling & 11,393 & 0.717 & 0.451 & 0 & 1 \\
Reduce Water Consumption & 11,393 & 0.425 & 0.494 & 0 & 1 \\
Reduce Energy Consumption & 11,393 & 0.572 & 0.498 & 0 & 1 \\
Purchase Labeled Products & 11,393 & 0.252 & 0.434 & 0 & 1 \\
Purchase Local Items & 11,393 & 0.301 & 0.459 & 0 & 1 \\
Reduce Car Usage & 11,393 & 0.243 & 0.429 & 0 & 1 \\
\hline
\end{tabular}


Table 4. Regression Results for Pro-Environmental Behaviors: $|\mathrm{k}| \leq 12$

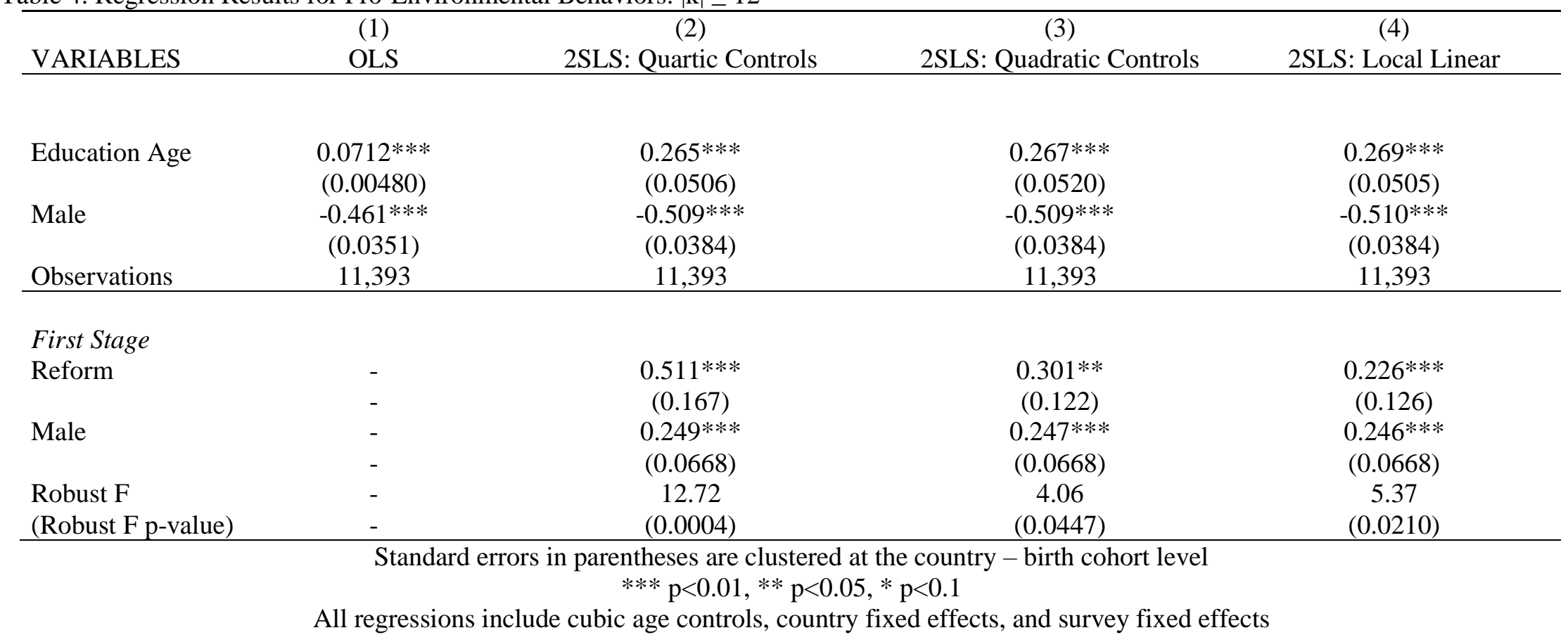


Table 5. Regression Results for Pro-Environmental Behaviors: $|\mathrm{k}| \leq 10$

\begin{tabular}{|c|c|c|c|c|}
\hline VARIABLES & $\begin{array}{l}(1) \\
\text { OLS }\end{array}$ & $\begin{array}{c}\text { (2) } \\
\text { 2SLS: Quartic Controls }\end{array}$ & $\begin{array}{c}(3) \\
\text { 2SLS: Quadratic Controls } \\
\end{array}$ & $\begin{array}{c}\text { (4) } \\
\text { 2SLS: Local Linear }\end{array}$ \\
\hline Education Age & $\begin{array}{c}0.0713 * * * \\
(0.00514)\end{array}$ & $\begin{array}{c}0.233 * * * \\
(0.0612)\end{array}$ & $\begin{array}{c}0.242 * * * \\
(0.0608)\end{array}$ & $\begin{array}{c}0.244 * * * \\
(0.0603)\end{array}$ \\
\hline $\begin{array}{l}\text { Male } \\
\text { Observations }\end{array}$ & $\begin{array}{c}-0.479 * * * \\
(0.0392) \\
9,657 \\
\end{array}$ & $\begin{array}{c}-0.519 * * * \\
(0.0423) \\
9,657\end{array}$ & $\begin{array}{c}-0.521 * * * \\
(0.0425) \\
9,657\end{array}$ & $\begin{array}{c}-0.522 * * * \\
(0.0425) \\
9,657\end{array}$ \\
\hline First Stage & & & & \\
\hline Reform & $\begin{array}{l}- \\
-\end{array}$ & $\begin{array}{c}0.605^{* * *} * \\
(0.223)\end{array}$ & $\begin{array}{c}0.442 * * * \\
(0.153)\end{array}$ & $\begin{array}{c}0.445^{* * *} \\
(0.153)\end{array}$ \\
\hline Male & $\begin{array}{l}- \\
-\end{array}$ & $\begin{array}{l}0.251^{* * * *} \\
(0.0727)\end{array}$ & $\begin{array}{l}0.249 * * * \\
(0.0727)\end{array}$ & $\begin{array}{l}0.249 * * * \\
(0.0727)\end{array}$ \\
\hline $\begin{array}{l}\text { Robust F } \\
\text { (Robust F p-value) }\end{array}$ & $\begin{array}{l}- \\
-\end{array}$ & $\begin{array}{c}8.57 \\
(0.0004)\end{array}$ & $\begin{array}{c}5.55 \\
(0.0191) \\
\end{array}$ & $\begin{array}{c}6.94 \\
(0.0088)\end{array}$ \\
\hline
\end{tabular}

Standard errors in parentheses are clustered at the country - birth cohort level $* * * \mathrm{p}<0.01, * * \mathrm{p}<0.05, * \mathrm{p}<0.1$

All regressions include cubic age controls, country fixed effects, and survey fixed effects 
Table 6. Regression Results for Individual Pro-Environmental Behaviors: $|\mathrm{k}| \leq 12$.

\begin{tabular}{|c|c|c|c|c|c|c|}
\hline & (1) & (2) & $(3)$ & $(1)$ & $(2)$ & (3) \\
\hline VARIABLES & OLS & Probit & 2SLS & OLS & Probit & 2SLS \\
\hline & \multicolumn{3}{|c|}{ Environmentally Friendly Travel } & \multicolumn{3}{|c|}{ Reduce Disposables } \\
\hline \multirow[t]{2}{*}{ Education Age } & $0.00974 * * *$ & $0.00975 * * *$ & $0.0242 *$ & $0.0121 * * *$ & $0.0125 * * *$ & $0.0300 * *$ \\
\hline & $(0.00126)$ & $(0.00127)$ & $(0.0134)$ & $(0.00122)$ & $(0.00128)$ & $(0.0122)$ \\
\hline \multirow[t]{3}{*}{ Male } & $-0.0398 * * *$ & $-0.0390 * * *$ & $-0.0436 * * *$ & $-0.110 * * *$ & $-0.109 * * *$ & $-0.114 * * *$ \\
\hline & $(0.00865)$ & $(0.00861)$ & $(0.00910)$ & $(0.00918)$ & $(0.00900)$ & $(0.00960)$ \\
\hline & \multicolumn{3}{|c|}{ Separate Waste } & \multicolumn{3}{|c|}{ Reduce Water Consumption } \\
\hline \multirow[t]{2}{*}{ Education Age } & $0.00680 * * *$ & $0.00667 * * *$ & $0.0659 * * *$ & $0.00586 * * *$ & $0.00586 * * *$ & -0.00467 \\
\hline & $(0.00122)$ & $(0.00118)$ & $(0.0130)$ & $(0.00121)$ & $(0.00121)$ & $(0.0128)$ \\
\hline \multirow[t]{3}{*}{ Male } & $-0.0477 * * *$ & $-0.0478 * * *$ & $-0.0621 * * *$ & $-0.0891 * * *$ & $-0.0886 * * *$ & $-0.0864 * * *$ \\
\hline & $(0.00822)$ & $(0.00814)$ & $(0.00975)$ & $(0.00893)$ & $(0.00882)$ & $(0.00972)$ \\
\hline & \multicolumn{3}{|c|}{ Reduce Energy Consumption } & \multicolumn{3}{|c|}{ Purchase Labeled Products } \\
\hline \multirow[t]{2}{*}{ Education Age } & $0.00707 * * *$ & $0.00703 * * *$ & $0.0270 * *$ & $0.0128 * * *$ & $0.0129 * * *$ & $0.0605 * * *$ \\
\hline & $(0.00122)$ & $(0.00121)$ & $(0.0133)$ & $(0.00116)$ & $(0.00118)$ & $(0.0122)$ \\
\hline \multirow[t]{3}{*}{ Male } & $-0.0485^{* * *} *$ & $-0.0486 * * *$ & $-0.0533 * * *$ & $-0.0780 * * *$ & $-0.0763 * * *$ & $-0.0893 * * *$ \\
\hline & $(0.00966)$ & $(0.00963)$ & $(0.0104)$ & $(0.00885)$ & $(0.00866)$ & $(0.00959)$ \\
\hline & \multicolumn{3}{|c|}{ Purchase Local Items } & \multicolumn{3}{|c|}{ Reduce Car Usage } \\
\hline \multirow[t]{2}{*}{ Education Age } & $0.00922 * * *$ & $0.00939 * * *$ & $0.0428 * * *$ & $0.00763 * * *$ & $0.00788 * * *$ & $0.0193^{*}$ \\
\hline & $(0.00114)$ & $(0.00120)$ & $(0.0113)$ & $(0.00108)$ & $(0.00113)$ & $(0.0115)$ \\
\hline \multirow[t]{2}{*}{ Male } & $-0.0655^{* * *} *$ & $-0.0648 * * *$ & $-0.0737 * * *$ & $0.0170^{* *}$ & $0.0178 * *$ & 0.0136 \\
\hline & $(0.00815)$ & $(0.00804)$ & $(0.00879)$ & $(0.00840)$ & $(0.00835)$ & $(0.00878)$ \\
\hline
\end{tabular}

All regressions include cubic age controls, quartic cohort trend controls, country fixed effects, and survey fixed effects.

Coefficients for Probit specifications represent average marginal effects. 
Table 7. Regression Results for Supporting Opinion Questions: $|\mathrm{k}| \leq 12$

\begin{tabular}{lcccccccc}
\hline & \multicolumn{2}{c}{ Personal Importance } & \multicolumn{2}{c}{ How Well Informed } & \multicolumn{2}{c}{ Influence on Quality of Life } & \multicolumn{2}{c}{ Direct Daily Effect on Life } \\
$(1)$ & $(2)$ & $(3)$ & $(4)$ & $(5)$ & $(6)$ & (7) & OLS & 2SLS \\
VARIABLES & OLS & 2SLS & OLS & 2SLS & OLS & 2SLS & OLS \\
\hline \multirow{2}{*}{ Education Age } & $0.00236^{* * *}$ & $0.0429 * * *$ & $-0.0186^{* * *}$ & -0.00270 & $0.00722^{* * *}$ & $0.0640^{* * *}$ & $0.00602 * * *$ & $0.0567 * * *$ \\
& $(0.000559)$ & $(0.00632)$ & $(0.00148)$ & $(0.0125)$ & $(0.00103)$ & $(0.0122)$ & $(0.00113)$ & $(0.0129)$ \\
Male & $-0.0160^{* * *}$ & $-0.0260^{* * *}$ & $-0.0279 * * *$ & $-0.0318^{* * *}$ & $-0.0116^{*}$ & $-0.0256^{* * *}$ & -0.0117 & $-0.0242^{* * *}$ \\
& $(0.00390)$ & $(0.00516)$ & $(0.00876)$ & $(0.00922)$ & $(0.00702)$ & $(0.00879)$ & $(0.00773)$ & $(0.00920)$ \\
Observations & 11,393 & 11,393 & 11,393 & 11,393 & 11,393 & 11,393 & 11,393 & 11,393 \\
\hline
\end{tabular}

Standard errors in parentheses are clustered at the country - birth cohort level

$$
* * * \mathrm{p}<0.01, * * \mathrm{p}<0.05, * \mathrm{p}<0.1
$$

All regressions include cubic age controls, country fixed effects, and survey fixed effects

All 2SLS regressions include quartic controls 


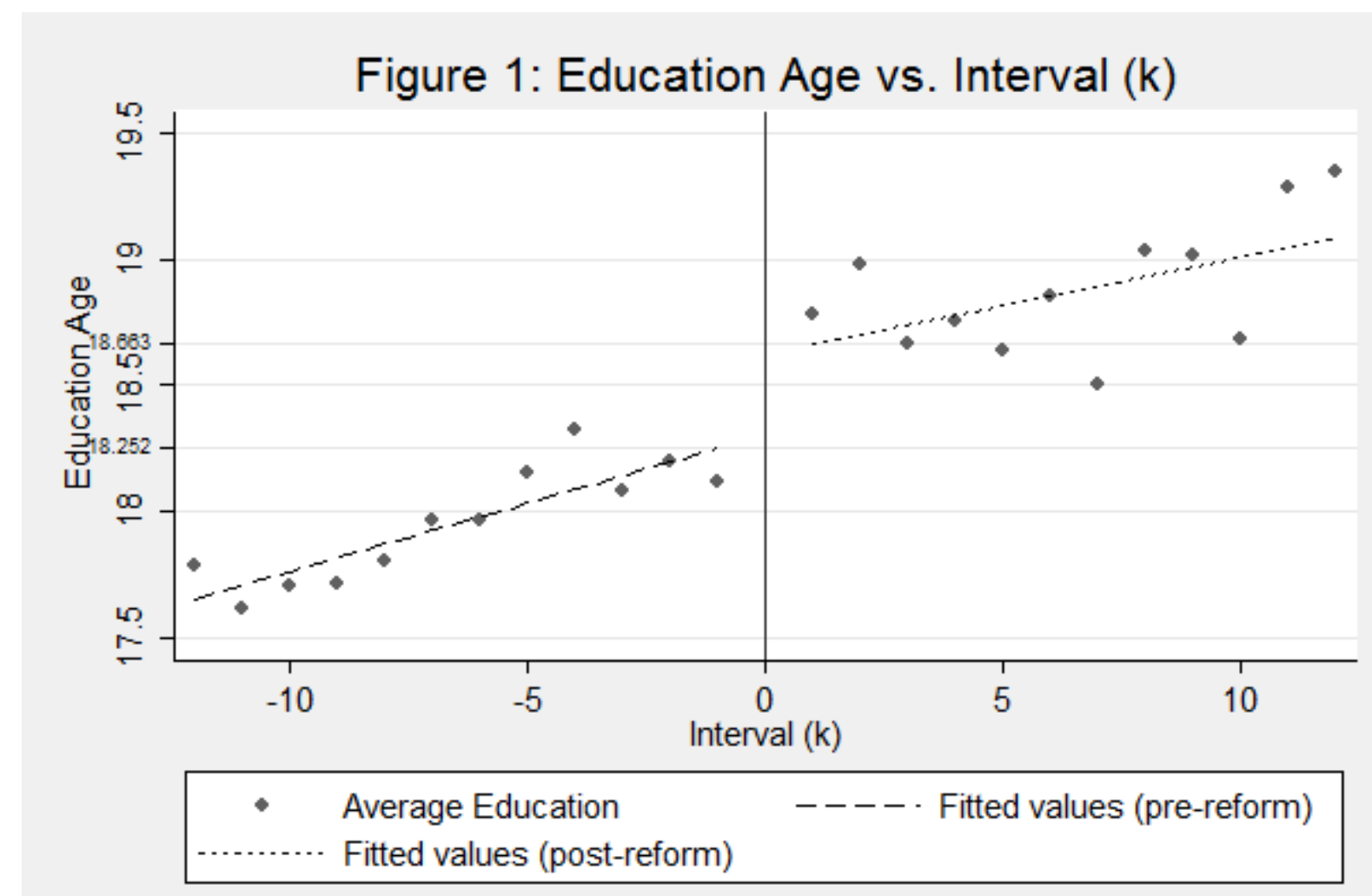

Note: Average education values represent means of all observations for a given $k$.

Fitted values are from the separate regressions of educationage on interval in the pre and post reform regions. 


\section{Appendix}

Table A1: Summary of Previous Studies Examining Relationship between Education and Pro-Environmental Behavior

\begin{tabular}{|c|c|c|c|c|c|c|c|}
\hline Paper & $\begin{array}{l}\text { Geography } \\
\text { and Data Year }\end{array}$ & Data & $\begin{array}{l}\text { Dependent } \\
\text { Variable }\end{array}$ & $\begin{array}{l}\text { Education } \\
\text { Variable }\end{array}$ & Controls & Methods & Result \\
\hline $\begin{array}{l}\text { Ayalon et } \\
\text { al., } 2014\end{array}$ & $\begin{array}{l}\text { OECD } \\
\text { countries, } \\
2011\end{array}$ & $\begin{array}{l}\text { cross- } \\
\text { sectional } \\
\text { survey }\end{array}$ & $\begin{array}{l}\text { waste } \\
\text { generation }\end{array}$ & not specified & not specified & not specified & No relationship \\
\hline $\begin{array}{l}\text { Bellows et } \\
\text { al., } 2008\end{array}$ & USA, 2003 & $\begin{array}{l}\text { cross- } \\
\text { sectional } \\
\text { survey }\end{array}$ & $\begin{array}{l}\text { frequency of } \\
\text { purchasing } \\
\text { organic foods }\end{array}$ & not specified & $\begin{array}{l}\text { shopping engagement, } \\
\text { political affiliation, age, } \\
\text { food production } \\
\text { knowledge }\end{array}$ & $\begin{array}{l}\text { bivariate } \\
\text { associations } \\
\text { and OLS }\end{array}$ & $\begin{array}{l}(+) \text { for both bivariate } \\
\text { and multivariate models }\end{array}$ \\
\hline $\begin{array}{l}\text { Berk et al., } \\
1993\end{array}$ & $\begin{array}{l}\text { Los Angeles } \\
\text { and San } \\
\text { Francisco Bay } \\
\text { Areas, } 1991\end{array}$ & $\begin{array}{l}\text { cross- } \\
\text { sectional } \\
\text { survey }\end{array}$ & $\begin{array}{l}\text { water saving } \\
\text { behavior }\end{array}$ & $\begin{array}{l}\text { years of } \\
\text { education }\end{array}$ & $\begin{array}{l}\text { social desirability index, } \\
\text { LA indicator, income, } \\
\text { occupation, children at } \\
\text { home, own dwelling, } \\
\text { have pool, have lawn or } \\
\text { garden }\end{array}$ & $\begin{array}{l}\text { quasi-MLE } \\
\text { Poisson } \\
\text { regression }\end{array}$ & $\begin{array}{l}\text { (+) but statistically } \\
\text { insignificant }\end{array}$ \\
\hline $\begin{array}{l}\text { Blend and } \\
\text { Ravenswaay, } \\
1999\end{array}$ & $\begin{array}{l}\text { USA, 1997- } \\
1998\end{array}$ & $\begin{array}{l}\text { cross- } \\
\text { sectional } \\
\text { survey }\end{array}$ & $\begin{array}{l}\text { intention to } \\
\text { purchase eco- } \\
\text { labeled apples }\end{array}$ & $\begin{array}{l}\text { years of } \\
\text { completed } \\
\text { education }\end{array}$ & $\begin{array}{l}\text { price, type of eco- } \\
\text { labeling, grocery vs } \\
\text { supermarket, frequency } \\
\text { of buying organic apples, } \\
\text { income, household size, } \\
\text { age, gender }\end{array}$ & $\begin{array}{l}\text { contingent } \\
\text { choice, } \\
\text { Cragg } \\
\text { Double- } \\
\text { Hurdle } \\
\text { Model, Tobit } \\
\text { Model }\end{array}$ & $\begin{array}{l}\text { (+) for probability of } \\
\text { eco-labeled purchase, } \\
\text { insignificant for } \\
\text { quantity of eco-labeled } \\
\text { purchase }\end{array}$ \\
\hline $\begin{array}{l}\text { Brecard et } \\
\text { al., } 2009\end{array}$ & Europe, 2007 & $\begin{array}{l}\text { cross- } \\
\text { sectional } \\
\text { survey }\end{array}$ & $\begin{array}{l}\text { desire for eco- } \\
\text { labeling of fish }\end{array}$ & $\begin{array}{l}\text { proxied with } \\
\text { professional } \\
\text { situation }\end{array}$ & $\begin{array}{l}\text { environmental attitudes, } \\
\text { seaside frequentation, } \\
\text { age, gender, marital } \\
\text { status, country effects, } \\
\text { localization of habitat }\end{array}$ & $\begin{array}{l}\text { ordered } \\
\text { probit } \\
\text { regression }\end{array}$ & $\begin{array}{l}\text { (+) for intellectual } \\
\text { profession }\end{array}$ \\
\hline $\begin{array}{l}\text { Callan and } \\
\text { Thomas, } \\
2006\end{array}$ & $\begin{array}{l}\text { Massachusetts, } \\
1990\end{array}$ & $\begin{array}{l}\text { cross- } \\
\text { sectional } \\
\text { city level }\end{array}$ & $\begin{array}{l}\text { municipal solid } \\
\text { waste, } \\
\text { municipal } \\
\text { recycling }\end{array}$ & $\begin{array}{l}\text { percentage of } \\
\text { town with } \\
\text { baccalaureate } \\
\text { education }\end{array}$ & $\begin{array}{l}\text { population, income per } \\
\text { capita, median age, } \\
\text { housing density, price of } \\
\text { waste disposal, frequency } \\
\text { of collections, recycling } \\
\text { grants }\end{array}$ & $\begin{array}{l}\text { simultaneous } \\
\text { equations, } \\
\text { 3SLS }\end{array}$ & $\begin{array}{l}\text { (+) quadratic } \\
\text { relationship between } \\
\text { education and municipal } \\
\text { recycling }\end{array}$ \\
\hline
\end{tabular}




\begin{tabular}{|c|c|c|c|c|c|c|c|}
\hline $\begin{array}{l}\text { De Silva and } \\
\text { Pownall, } \\
2014\end{array}$ & $\begin{array}{l}\text { Netherlands, } \\
2010\end{array}$ & $\begin{array}{l}\text { cross- } \\
\text { sectional } \\
\text { survey }\end{array}$ & $\begin{array}{l}4 \text { attitudes } \\
\text { toward } \\
\text { sustainability (1 } \\
\text { to } 10 \text { scale) }\end{array}$ & $\begin{array}{l}\text { high school, } \\
\text { college indicators }\end{array}$ & $\begin{array}{l}\text { gender, mortgage owner, } \\
\text { age, \# children, income, } \\
\text { regional/city controls }\end{array}$ & $\begin{array}{l}\text { OLS, } \\
\text { matching } \\
\text { estimation }\end{array}$ & $\begin{array}{l}(+) \text { for college } \\
\text { education in } 3 \text { of } 4 \\
\text { attitudes. }(+) \text { for high } \\
\text { school education in } 1 \\
\text { attitude }\end{array}$ \\
\hline $\begin{array}{l}\text { Duggal et } \\
\text { al., } 1991\end{array}$ & $\begin{array}{l}\text { Pennsylvania } \\
\text { and New } \\
\text { Jersey, } 1980\end{array}$ & $\begin{array}{l}\text { cross- } \\
\text { sectional } \\
\text { city level }\end{array}$ & $\begin{array}{l}\text { newspaper and } \\
\text { glass recycling }\end{array}$ & $\begin{array}{l}\% \text { of population } \\
\text { over } 25 \text { with } 4 \text { or } \\
\text { more years of } \\
\text { college }\end{array}$ & $\begin{array}{l}\text { family median income, } \\
\text { availability of curbside } \\
\text { pickup }\end{array}$ & OLS & $\begin{array}{l}(+) \text { in most of the } \\
\text { models }\end{array}$ \\
\hline $\begin{array}{l}\text { Ek and } \\
\text { Soderholm, } \\
2008\end{array}$ & Sweden, 2004 & $\begin{array}{l}\text { cross- } \\
\text { sectional } \\
\text { survey }\end{array}$ & $\begin{array}{l}\text { WTP for green } \\
\text { electricity }\end{array}$ & $\begin{array}{l}\text { indicator for } \\
\text { university degree }\end{array}$ & $\begin{array}{l}\text { electricity price, electric } \\
\text { heating, self-image } \\
\text { controls, perception of } \\
\text { green benefits, gender, } \\
\text { age, presence of social } \\
\text { norm }\end{array}$ & $\begin{array}{l}\text { probit } \\
\text { regression }\end{array}$ & $\begin{array}{l}(+) \text { in } 1 \text { of } 3 \text { reported } \\
\text { models }\end{array}$ \\
\hline $\begin{array}{l}\text { Ferrara and } \\
\text { Missios, } \\
2005\end{array}$ & $\begin{array}{l}\text { Ontario, } \\
\text { Canada, } 2002\end{array}$ & $\begin{array}{l}\text { cross- } \\
\text { sectional } \\
\text { survey }\end{array}$ & $\begin{array}{l}\text { recycling } \\
\text { participation }(7 \\
\text { categories) }\end{array}$ & $\begin{array}{l}\text { highest education } \\
\text { level attained }\end{array}$ & $\begin{array}{l}\text { price, weekly recycling, } \\
\text { free units, unit limit, } \\
\text { mandatory recycling, } \\
\text { home ownership, income, } \\
\text { household size, age }\end{array}$ & $\begin{array}{l}\text { ordered } \\
\text { probit } \\
\text { regression }\end{array}$ & $\begin{array}{l}(+) \text { for post-grad in } 4 \text { of } \\
7 \text { recycling categories, } \\
\text { several other education } \\
\text { levels }(+) \text { for some } \\
\text { recycling categories }\end{array}$ \\
\hline $\begin{array}{l}\text { Gilg and } \\
\text { Barr, } 2006\end{array}$ & $\begin{array}{l}\text { Devon, UK, } \\
\text { date not } \\
\text { reported }\end{array}$ & $\begin{array}{l}\text { cross- } \\
\text { sectional } \\
\text { survey }\end{array}$ & $\begin{array}{l}\text { water saving } \\
\text { behavior }\end{array}$ & $\begin{array}{l}\text { level of formal } \\
\text { education }\end{array}$ & none & $\begin{array}{l}\text { cluster } \\
\text { analysis }\end{array}$ & $\begin{array}{l}\text { significant differences } \\
\text { in education levels } \\
\text { across clusters }\end{array}$ \\
\hline $\begin{array}{l}\text { Grafton, } \\
2014\end{array}$ & $\begin{array}{l}\text { OECD } \\
\text { countries, } \\
2011\end{array}$ & $\begin{array}{l}\text { cross- } \\
\text { sectional } \\
\text { survey }\end{array}$ & $\begin{array}{l}\text { several water } \\
\text { saving } \\
\text { behaviors }\end{array}$ & $\begin{array}{l}\text { years of post- } \\
\text { secondary } \\
\text { education }\end{array}$ & none & $\begin{array}{l}\text { correlation } \\
\text { coefficient }\end{array}$ & $\begin{array}{l}\text { (-) for plugging sink } \\
\text { while washing dishes, } \\
\text { recycling rain water, } \\
\text { taking shower instead of } \\
\text { bath; no relationship for } \\
\text { turn off water while } \\
\text { brushing teeth, water } \\
\text { garden in coolest part of } \\
\text { day }\end{array}$ \\
\hline $\begin{array}{l}\text { Johnston et } \\
\text { al., } 2001\end{array}$ & $\begin{array}{l}\text { USA and } \\
\text { Norway, } \\
\text { 1998-1999 }\end{array}$ & $\begin{array}{l}\text { cross- } \\
\text { sectional } \\
\text { survey }\end{array}$ & $\begin{array}{l}\text { preferences for } \\
\text { ecolabeled } \\
\text { seafood }\end{array}$ & $\begin{array}{l}\text { indicator for at } \\
\text { least a } 4-y r \\
\text { degree }\end{array}$ & $\begin{array}{l}\text { member of environmental } \\
\text { organization, frequency } \\
\text { of consuming seafood, } \\
\text { seafood budget, gender, } \\
\text { age, income }\end{array}$ & $\begin{array}{l}\text { contingent } \\
\text { choice, logit } \\
\text { model }\end{array}$ & $\begin{array}{l}\text { (-) for Norwegian } \\
\text { households, } \\
\text { insignificant for USA } \\
\text { households }\end{array}$ \\
\hline
\end{tabular}




\begin{tabular}{|c|c|c|c|c|}
\hline $\begin{array}{l}\text { Klineberg et } \\
\text { al., } 1998\end{array}$ & $\begin{array}{l}\text { Texas, 1990- } \\
1996\end{array}$ & $\begin{array}{l}\text { pooled } \\
\text { cross- } \\
\text { sectional } \\
\text { surveys }\end{array}$ & $\begin{array}{l}4 \text { measures of } \\
\text { environmental } \\
\text { concern }\end{array}$ & $\begin{array}{l}\text { years of } \\
\text { education }\end{array}$ \\
\hline
\end{tabular}

$\begin{array}{lllll}\text { Kriström and } & \text { OECD } & \text { cross- } & \text { WTP for green } & \text { energy, } \\ \text { Kiran, } 2014 & \text { countries, } & \text { sectional } & \begin{array}{l}\text { years of } \\ \text { electricity }\end{array} & \begin{array}{l}\text { secondary } \\ \text { education }\end{array}\end{array}$

$\begin{array}{llll}\begin{array}{l}\text { Millock and } \\ \text { Nauges, } \\ 2014\end{array} & \begin{array}{l}\text { OECD } \\ \text { countries, }\end{array} & \begin{array}{l}\text { cross- } \\ \text { sectional } \\ \text { survey }\end{array} & \begin{array}{l}\text { organic food } \\ \text { consumption }\end{array} \\ \text { Monier et } & \text { France, 2005 } & \begin{array}{l}\text { revealed } \\ \text { preference } \\ \text { grocery } \\ \text { store } \\ \text { choices }\end{array} & \begin{array}{l}\text { purchase of } \\ \text { organic eggs } \\ \text { and milk }\end{array} \\ & & & \end{array}$

$\begin{array}{lll}\text { Poortinga et } & \begin{array}{l}\text { Netherlands, } \\ \text { al., 2004 }\end{array} & \begin{array}{l}\text { cross- } \\ \text { sectional } \\ \text { survey }\end{array}\end{array}$

gender, age, ethnicity, size of town, income, political ideology,

indicator for at least one year post high school education

not specified choices

level of education, units not specified environmental quality, religiosity

income, member of environmental

organization, energy behavior index, index of concern for climate change, home size, household size, home type, years in residence, urban, age, gender, marital status, employment status

logistic,

Poisson

(+) for almost all

regressions measures of concern

OLS, Tobit, Hurdle

model,

Exponential type II Tobit energy, no significant relationship for electricity demand

not reported

not specified

no significant

relationship

discrete

choice,

multivariate

(+) in increasing cross-

income, age, family size

logit

complementarity

between choices of organic products

age, income, household size, self-enhancement, self-direction, openness to change, maturity, family, health and safety, achievement, new

(-) for home energy use, (+) for transport energy use environmental paradigm, concern about global warming 


\begin{tabular}{|c|c|c|c|c|c|c|c|}
\hline $\begin{array}{l}\text { Reschovsky } \\
\text { and Stone, } \\
1994\end{array}$ & $\begin{array}{l}\text { Finger Lakes } \\
\text { region of } \\
\text { upstate New } \\
\text { York }\end{array}$ & $\begin{array}{l}\text { cross- } \\
\text { sectional } \\
\text { survey }\end{array}$ & $\begin{array}{l}5 \text { household } \\
\text { recycling } \\
\text { behaviors }\end{array}$ & $\begin{array}{l}\text { level of education } \\
\text { (beyond HS } \\
\text { degree, bachelor's } \\
\text { degree, and } \\
\text { graduate or } \\
\text { professional } \\
\text { degree) }\end{array}$ & $\begin{array}{l}\text { and knowledge of } \\
\text { recycling programs, } \\
\text { household size, marital } \\
\text { status, gender, age, } \\
\text { number of hours worked } \\
\text { per week, income }\end{array}$ & $\begin{array}{l}\text { probit } \\
\text { regression }\end{array}$ & $\begin{array}{l}\text { beyond HS degree }(+) \\
\text { for } 3 \text { behaviors, } \\
\text { bachelor's }(+) \text { for } 4 \\
\text { behaviors, graduate }(+) \\
\text { for } 4 \text { behaviors }\end{array}$ \\
\hline $\begin{array}{l}\text { Rowlands et } \\
\text { al., } 2003\end{array}$ & $\begin{array}{l}\text { Waterloo, } \\
\text { Ontario, } \\
\text { Canada, 2000- } \\
2001\end{array}$ & $\begin{array}{l}\text { cross- } \\
\text { sectional } \\
\text { survey }\end{array}$ & $\begin{array}{l}\text { willingness to } \\
\text { pay premium } \\
\text { for green } \\
\text { electricity }\end{array}$ & $\begin{array}{l}\text { indicators for } \\
\text { highest level } \\
\text { achieved (high } \\
\text { school or less, } \\
\text { some college, } \\
\text { bachelor degree, } \\
\text { graduate degree) }\end{array}$ & none & $\begin{array}{l}\text { Spearman's } \\
\text { correlation }\end{array}$ & $(+)$ association \\
\hline Smith, 1995 & USA, 1993 & $\begin{array}{l}\text { cross- } \\
\text { sectional } \\
\text { survey }\end{array}$ & $\begin{array}{l}\text { contributing } \\
\text { money to } \\
\text { environmental } \\
\text { groups, signing } \\
\text { petition about } \\
\text { environmental } \\
\text { issues, }\end{array}$ & $\begin{array}{l}\text { years of } \\
\text { education, college } \\
\text { major }\end{array}$ & $\begin{array}{l}\text { income, gender, age, } \\
\text { race, support of } \\
\text { environmental laws, } \\
\text { science and } \\
\text { environmental knowledge }\end{array}$ & $\begin{array}{l}\text { probit } \\
\text { regression }\end{array}$ & $\begin{array}{l}(+) \text { for recycling, not } \\
\text { statistically significant } \\
\text { for other behaviors, } \\
\text { majors mostly not } \\
\text { significant }\end{array}$ \\
\hline $\begin{array}{l}\text { Teisl et al., } \\
2008\end{array}$ & Maine, 2004 & $\begin{array}{l}\text { cross- } \\
\text { sectional } \\
\text { survey }\end{array}$ & $\begin{array}{l}\text { recycling } \\
\text { credibility of } \\
\text { ecolabel } \\
\text { information, } \\
\text { perceived } \\
\text { environmental } \\
\text { friendliness of } \\
\text { vehicle, } \\
\text { importance of } \\
\text { label } \\
\text { information }\end{array}$ & $\begin{array}{l}\text { years of } \\
\text { education }\end{array}$ & $\begin{array}{l}\text { gender, age, some } \\
\text { environmental } \\
\text { belief/concern measures }\end{array}$ & $\begin{array}{l}\text { simultaneous } \\
\text { equations, } \\
\text { ordered } \\
\text { probit }\end{array}$ & $\begin{array}{l}\text { (+) for credibility and } \\
\text { importance of ecolabel, } \\
\text { (-) for perceived } \\
\text { environmental } \\
\text { friendliness }\end{array}$ \\
\hline $\begin{array}{l}\text { Thompson } \\
\text { and Kidwell, } \\
1998\end{array}$ & $\begin{array}{l}\text { Tucson, AZ, } \\
1994\end{array}$ & $\begin{array}{l}\text { revealed } \\
\text { preference } \\
\text { grocery } \\
\text { store } \\
\text { choices }\end{array}$ & $\begin{array}{l}\text { purchase of } \\
\text { organic } \\
\text { produce }\end{array}$ & $\begin{array}{l}\text { indicators for } \\
\text { level of education } \\
\text { (college degree } \\
\text { and graduate or } \\
\text { professional } \\
\text { degree) }\end{array}$ & $\begin{array}{l}\text { cosmetic defects, price, } \\
\text { income, age, number of } \\
\text { children in household, } \\
\text { gender, distance to } \\
\text { grocery store }\end{array}$ & $\begin{array}{l}\text { random } \\
\text { utility } \\
\text { discrete } \\
\text { choice } \\
\text { model }\end{array}$ & $\begin{array}{l}\text { (-) for graduate or } \\
\text { professional degree }\end{array}$ \\
\hline
\end{tabular}




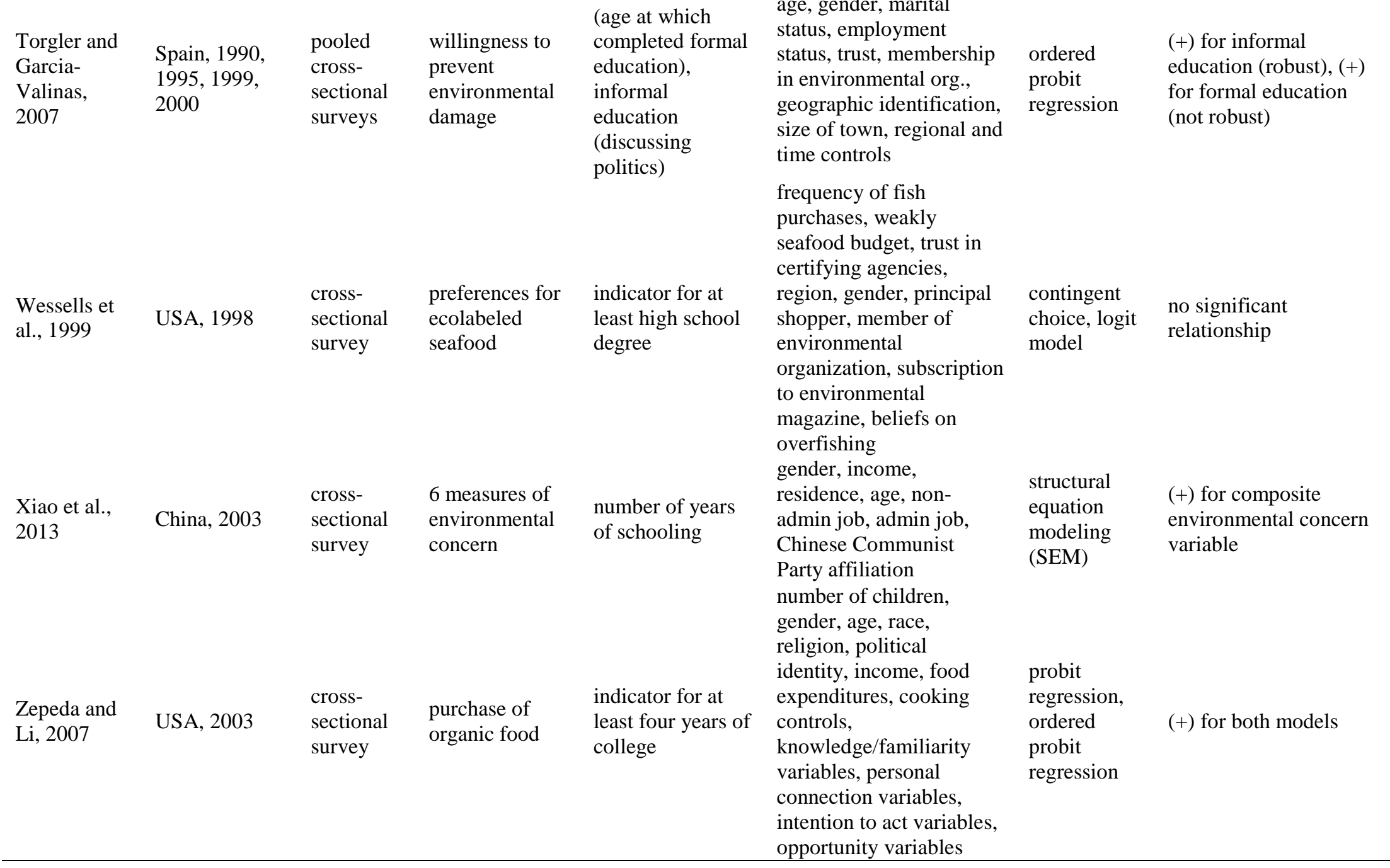

Note: (+) / (-) indicates positive / negative and statistically significant relationship between education and dependent variable, as defined in the table. Controls are the reported controls included in a multivariate analysis. "None" in the Controls column indicates bivariate analysis. 
Table A2. Regression Results for Pro-Environmental Behaviors: $|\mathrm{k}| \leq 8$

\begin{tabular}{|c|c|c|c|c|}
\hline VARIABLES & $\begin{array}{l}(1) \\
\text { OLS }\end{array}$ & $\begin{array}{c}(2) \\
\text { 2SLS: Quartic Controls }\end{array}$ & $\begin{array}{c}\text { (3) } \\
\text { 2SLS: Quadratic Controls }\end{array}$ & $\begin{array}{c}(4) \\
\text { 2SLS: Local Linear }\end{array}$ \\
\hline Education Age & $\begin{array}{c}0.0718 * * * \\
(0.00588)\end{array}$ & $\begin{array}{c}0.135^{*} \\
(0.0759)\end{array}$ & $\begin{array}{l}0.171 * * \\
(0.0803)\end{array}$ & $\begin{array}{l}0.175 * * \\
(00799)\end{array}$ \\
\hline Observations & $\begin{array}{c}-0.470 * * * \\
(0.0446) \\
7,769\end{array}$ & $\begin{array}{c}-0.487 * * * \\
(0.0482) \\
7.769\end{array}$ & $\begin{array}{c}-0.497 * * * \\
(0.0492) \\
7.769\end{array}$ & $\begin{array}{c}-0.497 * * * \\
(0.0492) \\
7769\end{array}$ \\
\hline First Stage & & & & \\
\hline Reform & $\begin{array}{l}- \\
-\end{array}$ & $\begin{array}{c}0.775^{* * * *} \\
(0.261)\end{array}$ & $\begin{array}{c}0.507 * * * \\
(0.0857)\end{array}$ & $\begin{array}{c}0.508 * * * \\
(0.175)\end{array}$ \\
\hline Male & $\begin{array}{l}- \\
-\end{array}$ & $\begin{array}{l}0.269 * * * \\
(0.0812)\end{array}$ & $\begin{array}{l}0.269 * * * \\
(0.0812)\end{array}$ & $\begin{array}{l}0.269 * * * \\
(0.0812)\end{array}$ \\
\hline $\begin{array}{l}\text { Robust F } \\
\text { (Robust F p-value) }\end{array}$ & $\begin{array}{l}- \\
-\end{array}$ & $\begin{array}{c}10.25 \\
(0.0015)\end{array}$ & $\begin{array}{c}7.16 \\
(0.0079)\end{array}$ & $\begin{array}{c}7.95 \\
(0.0052)\end{array}$ \\
\hline
\end{tabular}

Standard errors in parentheses are clustered at the country - birth cohort level $* * * \mathrm{p}<0.01, * * \mathrm{p}<0.05, * \mathrm{p}<0.1$

All regressions include cubic age controls, country fixed effects, and survey fixed effects 
Table A3. Regression Results for Pro-Environmental Behaviors: $|\mathrm{k}| \leq 6$

\begin{tabular}{|c|c|c|c|c|}
\hline VARIABLES & $\begin{array}{l}(1) \\
\text { OLS }\end{array}$ & $\begin{array}{c}\text { (2) } \\
\text { 2SLS: Quartic Controls }\end{array}$ & $\begin{array}{c}(3) \\
\text { 2SLS: Quadratic Controls } \\
\end{array}$ & $\begin{array}{c}\text { (4) } \\
\text { 2SLS: Local Linear }\end{array}$ \\
\hline Education Age & $\begin{array}{c}0.0749 * * * \\
(0.00718)\end{array}$ & $\begin{array}{l}0.226 * \\
(0.120)\end{array}$ & $\begin{array}{l}0.200 * \\
(0.119)\end{array}$ & $\begin{array}{l}0.231^{*} \\
(0119)\end{array}$ \\
\hline $\begin{array}{l}\text { Male } \\
\text { Observations }\end{array}$ & $\begin{array}{c}-0.487 * * * \\
(0.0533) \\
5,793 \\
\end{array}$ & $\begin{array}{c}-0.519 * * * \\
(0.0575) \\
5,793\end{array}$ & $\begin{array}{c}-0.514 * * * \\
(0.0586) \\
5,793\end{array}$ & $\begin{array}{c}-0.520 * * * \\
(0.0577) \\
5,793\end{array}$ \\
\hline First Stage & & & & \\
\hline Reform & $\begin{array}{l}- \\
-\end{array}$ & $\begin{array}{c}0.880 * * * \\
(0.325)\end{array}$ & $\begin{array}{l}0.575 * * * \\
(0.209)\end{array}$ & $\begin{array}{l}0.576^{* * * *} \\
(0.209)\end{array}$ \\
\hline Male & $\begin{array}{l}- \\
-\end{array}$ & $\begin{array}{l}0.209 * * \\
(0.0924)\end{array}$ & $\begin{array}{l}0.208 * * \\
(0.0924)\end{array}$ & $\begin{array}{l}0.208 * * * \\
(0.0924)\end{array}$ \\
\hline $\begin{array}{l}\text { Robust F } \\
\text { (Robust F p-value) }\end{array}$ & $\begin{array}{l}- \\
-\end{array}$ & $\begin{array}{c}9.28 \\
(0.0026)\end{array}$ & $\begin{array}{c}8.09 \\
(0.0049) \\
\end{array}$ & $\begin{array}{c}8.47 \\
(0.0040)\end{array}$ \\
\hline
\end{tabular}

Standard errors in parentheses are clustered at the country - birth cohort level $* * * \mathrm{p}<0.01, * * \mathrm{p}<0.05, * \mathrm{p}<0.1$

All regressions include cubic age controls, country fixed effects, and survey fixed effects 
Table A4. Regression Results for Pro-Environmental Behaviors, No Time Controls: $|\mathrm{k}| \leq 2,3$, and 4

\begin{tabular}{|c|c|c|c|}
\hline VARIABLES & $\begin{array}{c}(1) \\
\text { 2SLS: }|\mathrm{k}| \leq 4\end{array}$ & $\begin{array}{c}(2) \\
\text { 2SLS: }|\mathrm{k}| \leq 3 \\
\end{array}$ & $\begin{array}{c}(2) \\
\text { 2SLS: }|k| \leq 2 \\
\end{array}$ \\
\hline Education Age & $\begin{array}{c}0.289 * * \\
(0.135)\end{array}$ & $\begin{array}{c}0.280 * * \\
(0.141)\end{array}$ & $\begin{array}{c}0.187 \\
(0.122)\end{array}$ \\
\hline Male & $\begin{array}{c}-0.487 * * * \\
(0.0687)\end{array}$ & $\begin{array}{l}-0.514 * * * \\
(0.0732)\end{array}$ & $\begin{array}{c}-0.489 * * * \\
(0.0906)\end{array}$ \\
\hline Observations & 3,813 & 2,844 & 1,872 \\
\hline First Stage & & & \\
\hline Reform & $\begin{array}{c}0.442 * * * \\
(0.135)\end{array}$ & $\begin{array}{c}0.541 * * * \\
(0.155)\end{array}$ & $\begin{array}{c}0.643 * * * \\
(0.185)\end{array}$ \\
\hline Male & $\begin{array}{c}0.245^{* *} \\
(0.112)\end{array}$ & $\begin{array}{c}0.208 \\
(0.130)\end{array}$ & $\begin{array}{c}0.297 \\
(0.159)\end{array}$ \\
\hline $\begin{array}{l}\text { Robust F } \\
\text { (Robust F p-value) }\end{array}$ & $\begin{array}{c}18.02 \\
(0.0000)\end{array}$ & $\begin{array}{c}18.17 \\
(0.0000)\end{array}$ & $\begin{array}{c}19.99 \\
(0.0000)\end{array}$ \\
\hline
\end{tabular}

Standard errors in parentheses are clustered at the country - birth cohort level

$$
* * * \mathrm{p}<0.01, * * \mathrm{p}<0.05, * \mathrm{p}<0.1
$$

All regressions include cubic age controls, country fixed effects, and survey fixed effects 
Table A5. Regression Results for Pro-Environmental Behaviors with Added Controls: $|\mathrm{k}| \leq 12$

\begin{tabular}{|c|c|c|c|c|}
\hline VARIABLES & $\begin{array}{l}(1) \\
\text { OLS }\end{array}$ & $\begin{array}{c}\text { (2) } \\
\text { 2SLS: Quartic Controls }\end{array}$ & $\begin{array}{c}(3) \\
\text { 2SLS: Quadratic Controls }\end{array}$ & $\begin{array}{c}\text { (4) } \\
\text { 2SLS: Local Linear }\end{array}$ \\
\hline Education Age & $\begin{array}{l}0.0717 * * * \\
(0.00489)\end{array}$ & $\begin{array}{c}0.221 * * * \\
(0.0462)\end{array}$ & $\begin{array}{c}0.220 * * * \\
(0.0468)\end{array}$ & $\begin{array}{c}0.219 * * * \\
(0.0456)\end{array}$ \\
\hline Male & $\begin{array}{c}-0.512 * * * \\
(0.0360)\end{array}$ & $\begin{array}{c}-0.502 * * * \\
(0.0377)\end{array}$ & $\begin{array}{c}-0.502 * * * \\
(0.0377)\end{array}$ & $\begin{array}{c}-0.502 * * * \\
(0.0376)\end{array}$ \\
\hline Household Size & $\begin{array}{l}0.0341^{* *} \\
(0.0160)\end{array}$ & $\begin{array}{c}0.0234 \\
(0.0197)\end{array}$ & $\begin{array}{c}0.0234 \\
(0.0198)\end{array}$ & $\begin{array}{c}0.0236 \\
(0.0196)\end{array}$ \\
\hline \multicolumn{5}{|l|}{ Marital Status } \\
\hline Single with Partner & $\begin{array}{c}0.0450 \\
(0.0672)\end{array}$ & $\begin{array}{c}0.0681 \\
(0.0749)\end{array}$ & $\begin{array}{c}0.0679 \\
(0.0753)\end{array}$ & $\begin{array}{c}0.0676 \\
(0.0751)\end{array}$ \\
\hline Single & $\begin{array}{l}-0.135 * * \\
(0.0635)\end{array}$ & $\begin{array}{l}-0.147 * * \\
(0.0675)\end{array}$ & $\begin{array}{l}-0.147 * * \\
(0.0675)\end{array}$ & $\begin{array}{l}-0.147 * * \\
(0.0673)\end{array}$ \\
\hline Divorced/Separated & $\begin{array}{l}-0.140 * * * \\
(0.0535)\end{array}$ & $\begin{array}{l}-0.108 \\
(0.0806)\end{array}$ & $\begin{array}{l}-0.108 \\
(0.0821)\end{array}$ & $\begin{array}{c}-0.109 \\
(0.0818)\end{array}$ \\
\hline Other & $\begin{array}{l}-0.180 * * \\
(0.0851)\end{array}$ & $\begin{array}{c}-0.000568 \\
(0.286)\end{array}$ & $\begin{array}{c}-0.00278 \\
(0.295)\end{array}$ & $\begin{array}{c}-0.00402 \\
(0.290)\end{array}$ \\
\hline Residence & & & & \\
\hline Small/middle town & $\begin{array}{c}-0.127 * * * \\
(0.0415)\end{array}$ & $\begin{array}{l}-0.165 * * \\
(0.0661)\end{array}$ & $\begin{array}{l}-0.164 * * \\
(0.0673)\end{array}$ & $\begin{array}{l}-0.164 * * \\
(0.0662)\end{array}$ \\
\hline Large Town/City & $\begin{array}{l}-0.210 * * * \\
(0.0440)\end{array}$ & $\begin{array}{c}-0.346^{*} \\
(0.202)\end{array}$ & $\begin{array}{l}-0.345^{*} \\
(0.208)\end{array}$ & $\begin{array}{l}-0.344^{*} \\
(0.204)\end{array}$ \\
\hline Employment Status & & & & \\
\hline Unemployed & $\begin{array}{c}0.0942 \\
(0.0780)\end{array}$ & $\begin{array}{c}0.288 \\
(0.289)\end{array}$ & $\begin{array}{c}0.286 \\
(0.298)\end{array}$ & $\begin{array}{c}0.284 \\
(0.292)\end{array}$ \\
\hline Home Maker & $\begin{array}{c}-0.162 * * * \\
(0.0588)\end{array}$ & $\begin{array}{l}0.0871 \\
(0.340)\end{array}$ & $\begin{array}{l}0.0844 \\
(0.351)\end{array}$ & $\begin{array}{l}0.0829 \\
(0.343)\end{array}$ \\
\hline Retired/Disabled & $\begin{array}{l}0.150 * * * \\
(0.0503)\end{array}$ & $\begin{array}{l}0.290^{*} \\
(0.157)\end{array}$ & $\begin{array}{l}0.288^{*} \\
(0.162)\end{array}$ & $\begin{array}{l}0.290^{*} \\
(0.156)\end{array}$ \\
\hline Observations & 11,330 & 11,330 & 11,330 & 11,330 \\
\hline
\end{tabular}

All regressions include cubic age controls, country fixed effects, and survey fixed effects. Respective omitted categories for additional controls are married, rural area, and employed. 
Table A6. Regression Results for Individual Pro-Environmental Behaviors with Added Controls: $|\mathrm{k}| \leq 12$.

\begin{tabular}{|c|c|c|c|c|c|c|}
\hline & (1) & (2) & (3) & (1) & $(2)$ & (3) \\
\hline VARIABLES & OLS & Probit & 2SLS & OLS & Probit & 2 SLS \\
\hline & \multicolumn{3}{|c|}{ Environmentally Friendly Travel } & \multicolumn{3}{|c|}{ Reduce Disposables } \\
\hline \multirow[t]{2}{*}{ Education Age } & $0.00887 * * *$ & $0.00882 * * *$ & 0.00483 & $0.01234 * * *$ & $0.0127 * * *$ & $0.0219 * *$ \\
\hline & $(0.00126)$ & $(0.00127)$ & $(0.00526)$ & $(0.00124)$ & $(0.00130)$ & $(0.0110)$ \\
\hline \multirow[t]{3}{*}{ Male } & $-0.0453 * * *$ & $-0.0444 * * *$ & $-0.0456 * * *$ & $-0.115^{* * *}$ & $-0.114 * * *$ & $-0.114 * * *$ \\
\hline & $(0.00918)$ & $(0.00900)$ & $(0.00924)$ & $(0.00983)$ & $(0.00960)$ & $(0.0100)$ \\
\hline & \multicolumn{3}{|c|}{ Separate Waste } & \multicolumn{3}{|c|}{ Reduce Water Consumption } \\
\hline \multirow[t]{2}{*}{ Education Age } & $0.00709 * * *$ & $0.00690 * * *$ & $0.0598 * * *$ & $0.00611^{* * *}$ & $0.00611 * * *$ & -0.000558 \\
\hline & $(0.00122)$ & $(0.00119)$ & $(0.0121)$ & $(0.00123)$ & $(0.001212$ & $(0.0115)$ \\
\hline \multirow[t]{3}{*}{ Male } & $-0.0542 * * *$ & $-0.0542 * * *$ & $-0.0506 * * *$ & $-0.0954 * * *$ & $-0.0948 * * *$ & $-0.0958 * * *$ \\
\hline & $(0.00849)$ & $(0.00847)$ & $(0.00929)$ & $(0.00941)$ & $(0.00925)$ & $(0.00931)$ \\
\hline & \multicolumn{3}{|c|}{ Reduce Energy Consumption } & \multicolumn{3}{|c|}{ Purchase Labeled Products } \\
\hline \multirow[t]{2}{*}{ Education Age } & $0.00730 * * *$ & $0.00727 * * *$ & $0.0267 * *$ & $0.0121 * * *$ & $0.0123 * * *$ & $0.0509 * * *$ \\
\hline & $(0.00125)$ & $(0.00124)$ & $(0.0123)$ & $(0.00118)$ & $(0.00120)$ & $(0.0106)$ \\
\hline \multirow[t]{3}{*}{ Male } & $-0.0568 * * *$ & $-0.0570 * * *$ & $-0.0553 * * *$ & $-0.0890 * * *$ & $-0.0865 * * *$ & $-0.0861 * * *$ \\
\hline & $(0.0102)$ & $(0.0102)$ & $(0.0103)$ & $(0.00943)$ & $(0.00898)$ & $(0.00977)$ \\
\hline & \multicolumn{3}{|c|}{ Purchase Local Items } & \multicolumn{3}{|c|}{ Reduce Car Usage } \\
\hline \multirow[t]{2}{*}{ Education Age } & $0.0102 * * *$ & $0.0106^{* * * *}$ & $0.0393 * * *$ & $0.00781^{* * *}$ & $0.00803 * * *$ & -0.00662 \\
\hline & $(0.00115)$ & $(0.00122)$ & $(0.0103)$ & $(0.00110)$ & $(0.00114)$ & $(0.00510)$ \\
\hline \multirow[t]{2}{*}{ Male } & $-0.0719 * * *$ & $-0.0709 * * *$ & $-0.0699 * * *$ & $0.0150^{*}$ & $0.0153^{*}$ & 0.0136 \\
\hline & $(0.00860)$ & $(0.00840)$ & $(0.00895)$ & $(0.00909)$ & $(0.00894)$ & $(0.00926)$ \\
\hline
\end{tabular}

All regressions include controls for household size, marital status, employment status, and location of residence, cubic age controls, quartic cohort trend controls, country fixed effects, and survey fixed effects. Coefficients for Probit specifications represent average marginal effects. 